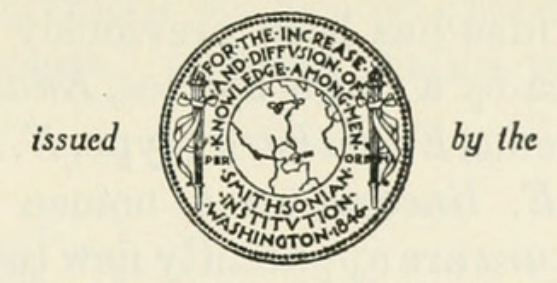

SMITHSONIAN INSTITUTION

U. S. NATIONAL MUSEUM

Vol. 101

Washington: 1951

No. 3273

\title{
NEW MARINE ISOPODS, CHIEFLY FROM NORTHERN CALIFORNIA, WITH NOTES ON RELATED FORMS
}

\section{By Robert J. Menzies}

Is THIs paper eight genera of marine Isopoda, including eleven species and one named variety, are described from the coast of northern California. Six of the genera are new to the fauna of the Pacific coast of North America. One genus and nine species are believed to be new to science.

In treating the janirid isopods (those included by Hansen, 1916, in his family Parasellidae) I have followed, primarily for convenience, the classification given by Nordenstam, 1933. This does not mean, however, that I advocate the use of that classification as a final one, for it has too many serious drawbacks, many of which were expressed by both Hansen and Nordenstam. At present I am not prepared to offer a new classification, to revise the old ones, or to correlate the old with the new, but I feel obligated to accept a reasonably recent classification that presumably is the best for the time being.

Acknowledgments are due Dr. Frank A. Pitelka, Zoology Department, University of California, for the loan of a large collection of marine isopods from Monterey, Calif., made by John Davis; Dr. Melville H. Hatch, Zoology Department, University of Washington, for the loan of many specimens, particularly types of species described by him; and Dr. John Mohr, Zoology Department, University of Southern California, for checking certain references not available to me. Particular thanks are due Dr. Fenner A. Chace, Jr., curator of marine invertebrates, U. S. National Museum, for his many helpful suggestions and worth-while criticisms, the loan of important material, the examination of type specimens, and his generous cooperation. 


\section{Family ANTHURIDAE}

The family Anthuridae has been previously known from the west coast of North America by a single species, Edanthura linearis Boone. I herein consider the genus Edanthura (type, E. linearis) as a synonym of Paranthura and $E$. linearis as a nomen nudum. The genera Colanthura and Cyathura are apparently new to the Pacific coast fauna of North America. The three genera concerned differ so widely from one another that their identification is relatively simple, as is illustrated in the following key:

\section{KEY TO THE KNOWN NORTHERN CALIFORNIAN GENERA OF THE FAMILY ANTHURIDAE}

$\boldsymbol{a}^{\mathbf{1}}$. Free portion of maxilliped consisting of a single article; mandibular palp lacking; only 6 pairs of peraeopods present Colanthura

$a^{2}$ Free portion of maxilliped consisting of 2 or 3 articles; mandibular palp present; 7 pairs of peraeopods present in adults.

$b^{1}$. Maxilliped with 2 free articles; mandibular incisor lacking chitinized teeth; mouth parts adapted for piercing and sucking _-_-_-_-_Paranthura

$b^{2}$. Maxilliped with 3 free articles; mandibular incisor with chitinized teeth; mouth parts adapted for chewing

Cyathura

\section{Genus PARANTHURA Bate and Westwood, 1868}

In addition to the synonyms listed by Dr. Barnard in his revision of the family (1925, p. 152), another genus, Edanthura Boone, 1923 (type, E. linearis Boone, 1923, nomen nudum), should be considered as a synonym of Paranthura.

\section{PARANTHURA ELEGANS, new species}

Figures 9-11

Holotype.-Female, length $9.1 \mathrm{~mm}$., width at widest part of second peraeon somite $0.8 \mathrm{~mm}$.

Allotype.-Male, length $9.0 \mathrm{~mm}$., width $0.5 \mathrm{~mm}$.

Diagnosis.-Cephalon anterolateral angles very slightly exceeding rostral forward extent. Eyes large, composed of about 13 ocelli. Endopod of uropod extending beyond telson; exopod shorter than telson and with a slightly sinuate posterolateral border. Tip of stylus of second male pleopod with four setae and marginal cylindroid lobe. Posterolateral pleotelson borders finely dentate. Maxilliped with two free articles.

Character of body.-Length exceeding nine times the width. Dull yellow in color with a few scattered dark-brown chromatophores.

Cephalon.-Rostral projection not exceeding forward extent of anterolateral angles. Eyes with about 13 ocelli. Ocular lobe with pointed apex as seen from lateral view.

Peraeon.-Second somite slightly longer than first and with a dorsal anterior depression for the reception of the posterior border of first somite. Third somite similar to second but shorter and wider. 
Fourth and fifth somites similar in length, being one-fourth longer than third somite and having a pit located anteriorly on each side of dorsolateral peraeon margin. Seventh somite one-half the length of sixth.
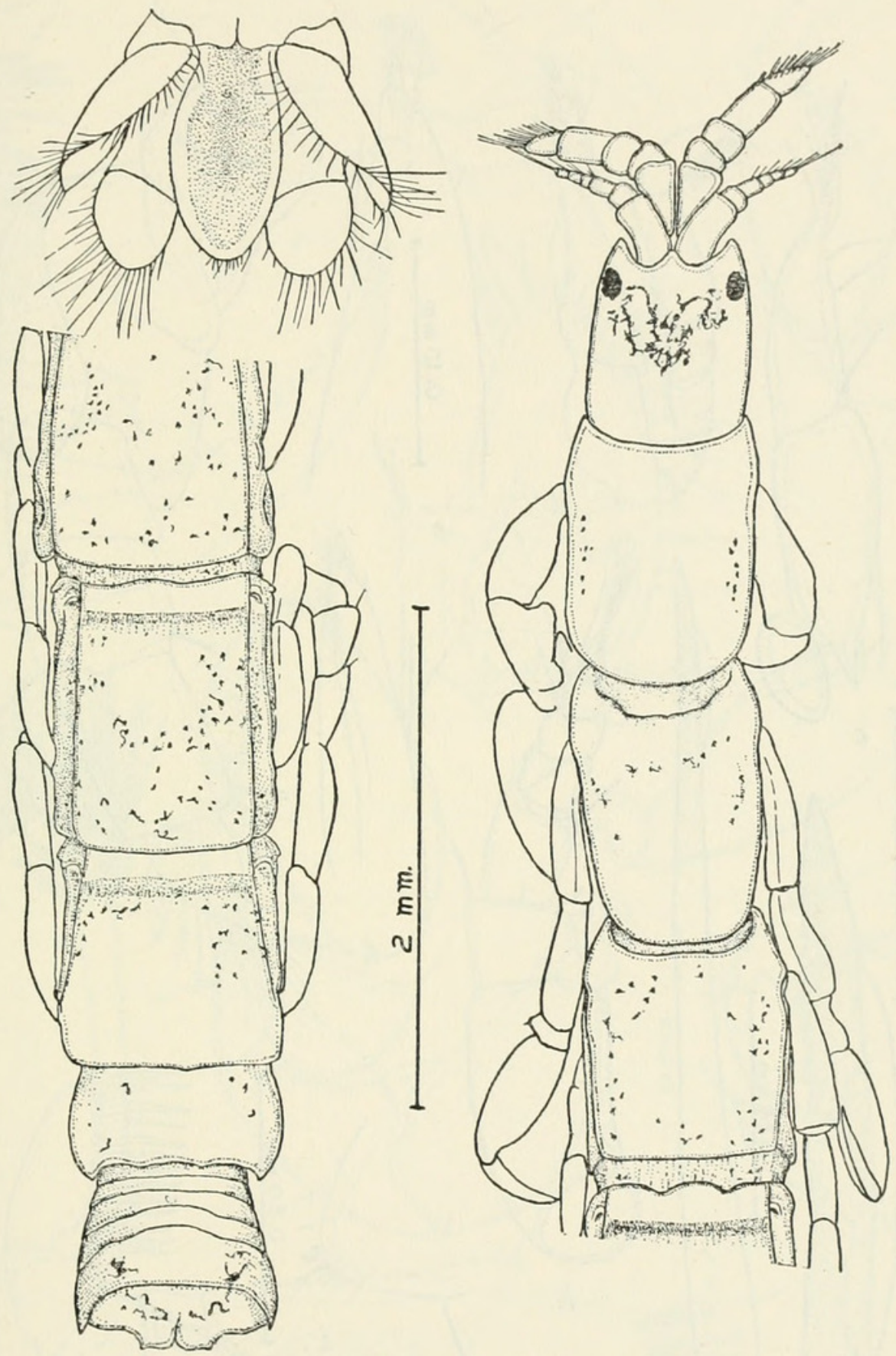

FigURE 9.-Paranthura elegans, new species: Holotype. (Magnification as indicated by scale.)

Pleon.-Demarcation of somites visible in dorsal view. First four somites similar in length. Fifth somite three times the length of fourth. Sixth somite with a pronounced posterior median cleft. Telson elongate, with an evenly convex setiferous posterior margin and finely serrate posterolateral borders.

First antenna.-Composed of eight joints. Fourth joint deeply immersed in distal part of third joint. 
Second antenna.-Peduncle composed of six joints the first three of which are partially fused with one another. Flagellum composed of a single setiferous, clavate joint bearing about three small indistinct joints at tip. Flagellum about one-half the length of sixth peduncular joint.

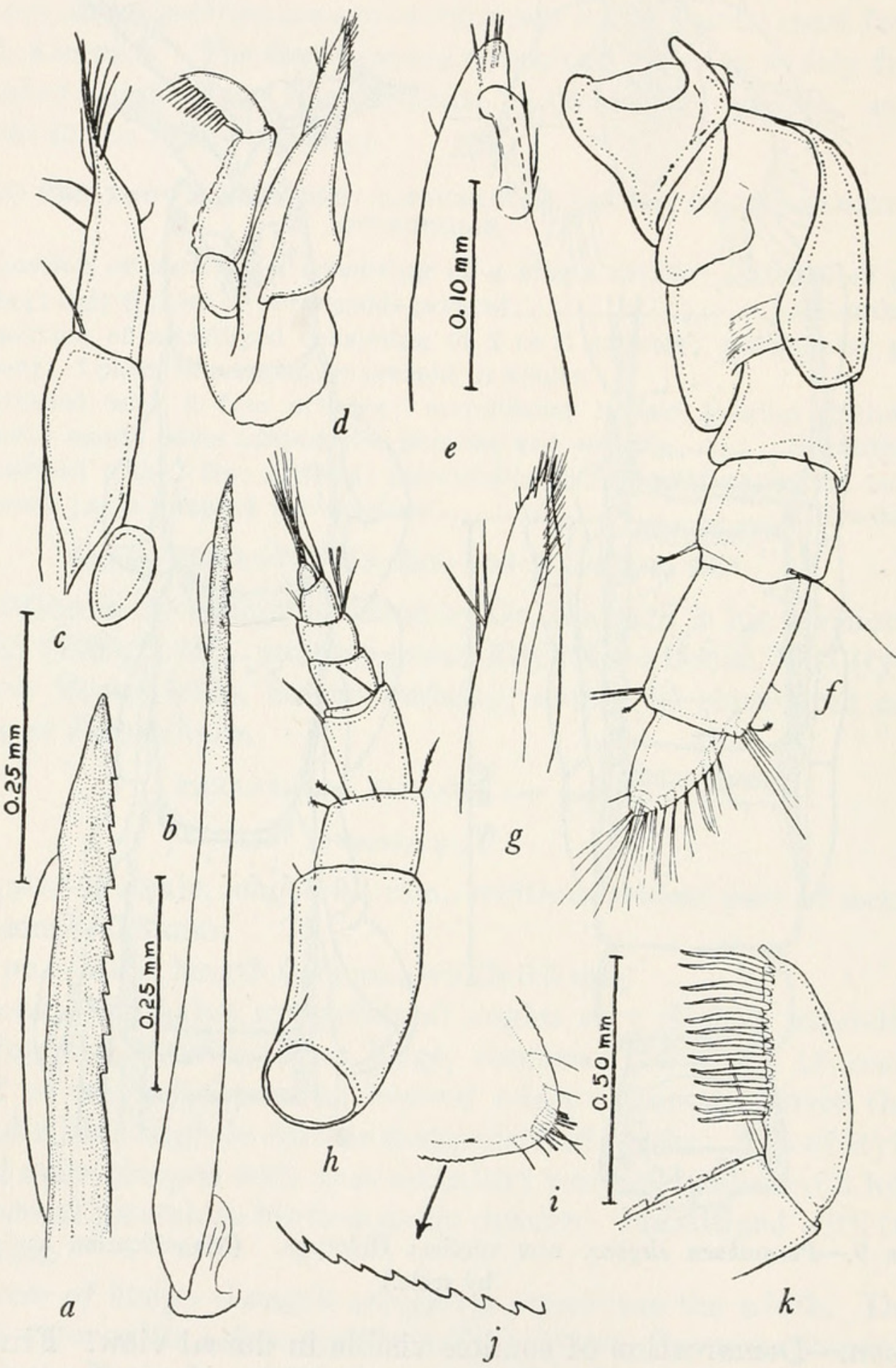

Figure 10.-Paranthura elegans, new species: $a$, Tip of first maxilla, female paratype; $b$, maxilla, female paratype; $c$, left maxilliped, female paratype; $d$, mandible, female paratype; $e$, tip of stylus of second male pleopod, paratype; $f$, second antenna, holotype; $g$, lower lip (?), female paratype; $h$, first antenna, holotype; $i$, posterior tip of telson, holotype; $j$, posterolateral border of telson, holotype; $k$, terminal joint of mandibular palp, female paratype. (Magnification as indicated by scales: $g$ and $k$ same as $a ; c, d, f, h$, and $j$ same as b.) 
Maxilliped.-With two free joints, last joint tapering to a very narrow tip.

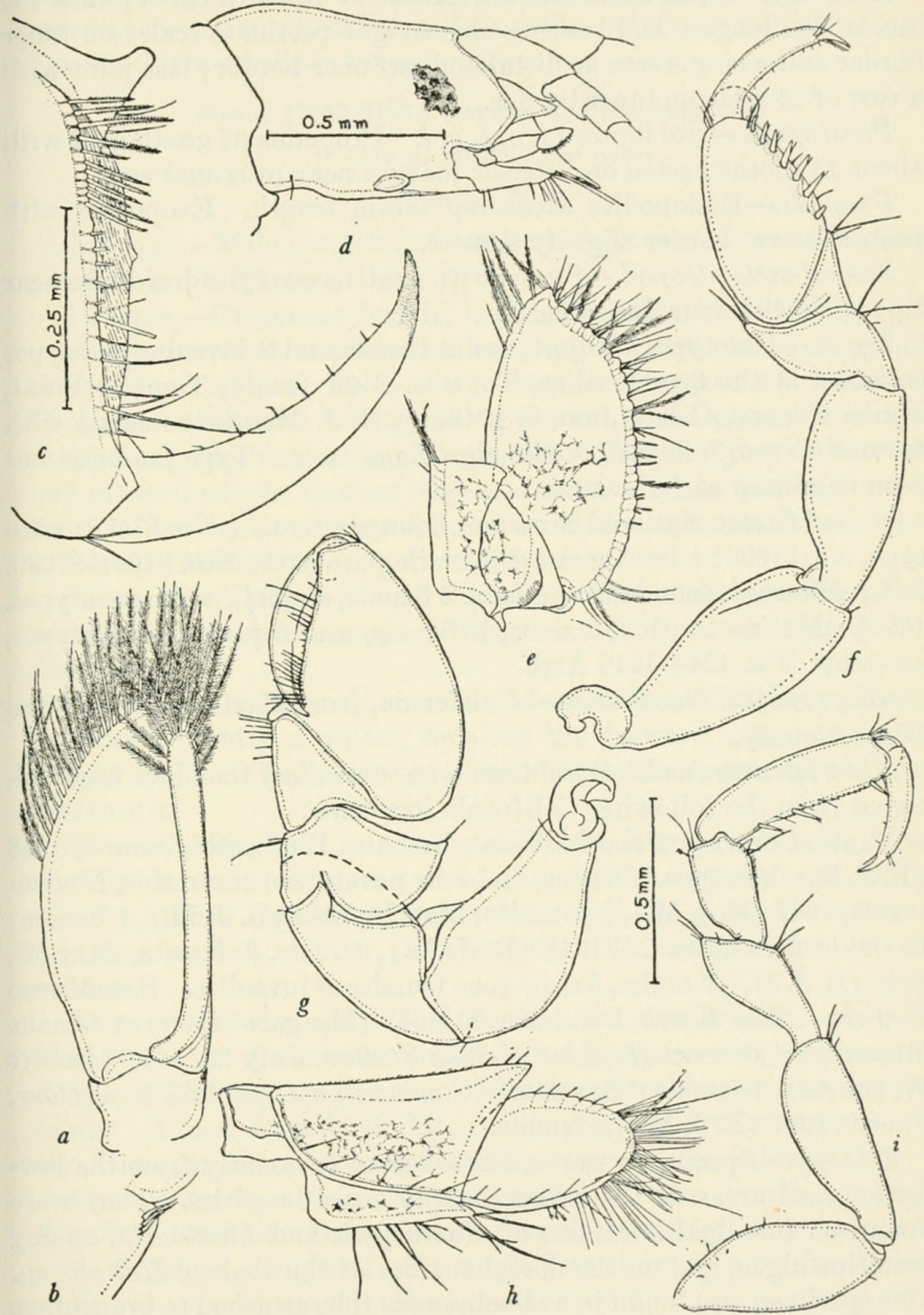

Figure 11.-Paranthura elegans, new species: $a$, First pleopod, holotype; $b$, spinelike setae on inner margin of basal segment of first pleopod, holotype; $c$, first peraeopod, distal joints, holotype; $d$, lateral view of cephalon, holotype; $e$, exopodite of uropod, dorsal surface; $f$, second peraeopod, holotype; $g$, first peraeopod, holotype; $h$, endopodite of uropod, dorsal surface; $i$, seventh peraeopod, holotype. (Magnification as indicated by scales: $e-i$ same as $a ; c$ same as $b$.) 
First maxilla.-Outer lobe with about twelve sawlike teeth.

Second maxilla.-Coalesced with lower lip, distally setiferous.

Mandible.-Apex acute and setiferous. Palp with three joints, the second the longest and bearing about eight pectinate scales on inner border and a single seta at distal end on inner border; last joint with a row of 14 setae on inner border.

Peraeopods.-See figure 11, $c, f, g, i$. Propodus of gnathopod with about 11 toothed setae on inferior margin near proximal end.

Uropods.-Endopodite exceeding telson length. Exopodite with posterolateral border slightly sinuate.

Second male pleopod.-Stylus with a setiferous cylindroid lobe near tip; apex with four fine setae.

Types.-Holotype, allotype, and 2 female and 2 juvenile paratypes collected at the type locality, Tomales Bluff (reef), Tomales Point, Marin County, Calif., June 9, 1948, by R. J. Menzies; washed with formalin from holdfast of the alga Laminaria. Type material has been deposited as follows:

United States National Museum, holotype female, No. 87692; allotype, No. 87693; 4 female and 4 juvenile paratypes, Nos. 87694-87696. Allan Hancock Foundation, 1 male, 2 female, and 2 juvenile paratypes. Pacific Marine Station, 2 male, 3 female, and 3 juvenile paratypes, accession Nos. 1244-1248 Arth.

Geographical distribution.-California, from Marin County to San Diego County.

Material examined.-Specimens were examined that had been collected from the following California localities:

Marin County: Tomales Point, Tomales Bluff, reef, June 9, 1948 (R. J. M.), holotype, allotype, and four paratypes; ocean side, November 28, 1947 (R. J. M.), 1 juvenile; May 23, 1948 (R. J. M.), 1 female; bay side, November 28, 1947 (R. J. M.), 1 male, 1 female; May 23, 1948 (R. J. M.), 3 males, 3 ovigerous females, 6 juveniles. S San Mateo County : Moss Beach, December 26, 1947 (Margaret Barr), 1 female. Monterey County: Hopkins Marine Station, July 23, 1947 (Robert. W. Storer), 1 female. SAN Diego County: La Jolla, Childrens Cove, June 9, 1947 (R. J. M.), 1 female.

Ecology.-Specimens were collected most frequently from the lowest exposed areas of the exposed rocky coast localities. They were found on the algal holdfasts of Macrocystis and Laminaria, among coralline algae, and on the dorsal surface of the abalone Hatiotis sp. One specimen was found in a membranous tube attached to branchings of a coralline alga, Bossea sp.

Remarks. - The description of the species Edanthura linearis Boone (1923, pp. 148-149) is hardly more than generic, and although it is easy to recognize that Edanthura is a synonym of Paranthura it is impossible to distinguish the species from the known species of Par- 
anthura. I therefore consider Edanthura linearis a nomen nudum. Small and juvenile specimens of Paranthura elegans differ from adult specimens in having very small and weakly developed seventh peraeopods and sixth peraeopod propodal joints beset with one less 2 -pointed seta on the inferior margins.

\section{Genus CYATHURA Norman and Stebbing, 1886}

\section{CYATHURA MUNDA, new species}

\section{Figures 12, 13}

Holotype-Male, length $5.2 \mathrm{~mm}$., width at widest part of second peraeon somite $0.5 \mathrm{~mm}$.

Allotype.-Ovigerous female, length $6.0 \mathrm{~mm}$., width $0.4 \mathrm{~mm}$.

Diagnosis.-Rostral projection equaling forward extent of cephalic anterolateral angles. Eyes small, number of ocelli not discerned. Uropodal endopodite not extending beyond telson posterior margin; exopodite posterolateral margin sinuate. Tip of stylus of male second pleopod simple, lacking lobes and setae. Telson posterior border concave, lateral borders smooth. Paired statocysts in anterior part of telson. Maxilliped with three free joints.

Character of body.-Length exceeding nine times the width. Color white with scattered clumps of black chromatophores, color pattern distinctive.

Cephalon.-Eyes small, number of ocelli not discerned. Rostral projection bluntly angulate, equaling the forward extent of anterolateral angles. Ocular lobe in lateral view with apex anteriorly ventral to eye.

Peraeon.-First six somites similar in length. Seventh somite slightly shorter than sixth. Second and third somites each with an anterior dorsal depression for reception of the posterior border of first and second somites, respectively. No keels, ridges, or pits evident.

Pleon.-The segmentation of the first five somites, although visible laterally, is not discernible dorsally. Sixth somite with a pronounced dorsal medial cleft on the line which separates that somite from the telson. Telson dorsally slightly swollen; lateral borders smooth, posterior margin concave; paired statocysts present in anterior end.

First antenna.-Peduncle composed of three joints. In male, flagellum brushlike, composed of four short setiferous joints; in female flagellum composed of a single joint having a setiferous knob at tip, which perhaps represents another joint.

Second antenna.-Peduncle composed of six segments. Flagellum with a single, tapering, setiferous joint, which is slightly longer than one-half the length of the last peduncular joint.

Maxilliped.-Composed of three wide free joints.

First maxilla.-Outer lobe with six marginal fingerlike teeth. 


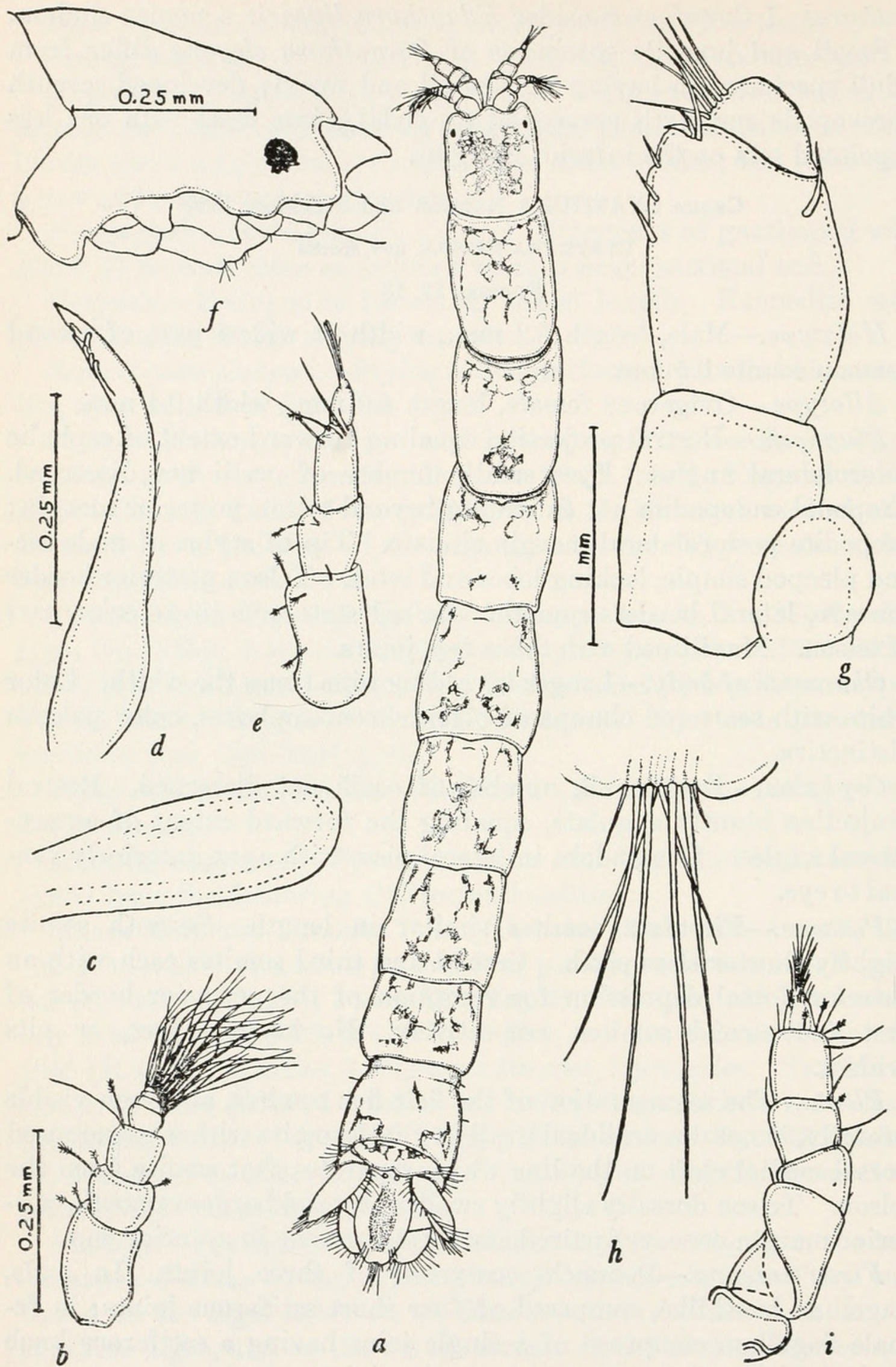

Figure 12.-Cyathura munda, new species: $a$, Holotype male; $b$, first antenna, holotype; c. tip of stylus of male second pleopod, holotype; $d$, first maxilla, right; $e$, first antenna, right, female paratype; $f$, lateral view of cephalon, holotype; $g$, maxilliped, left, female paratype; $h$, tip of telson, holotype; $i$, second antenna, holotype. (Magnification as indicated by scales: $e$ and $i$ same as $b ; d, g$, and $h$ same as $c$.) 
Mandible.-Left and right mandibles similar. Incisor process with five small teeth. A thin flange having five teeth located proximal to incisor. Molar process short and blunt. Palp with three joints, last

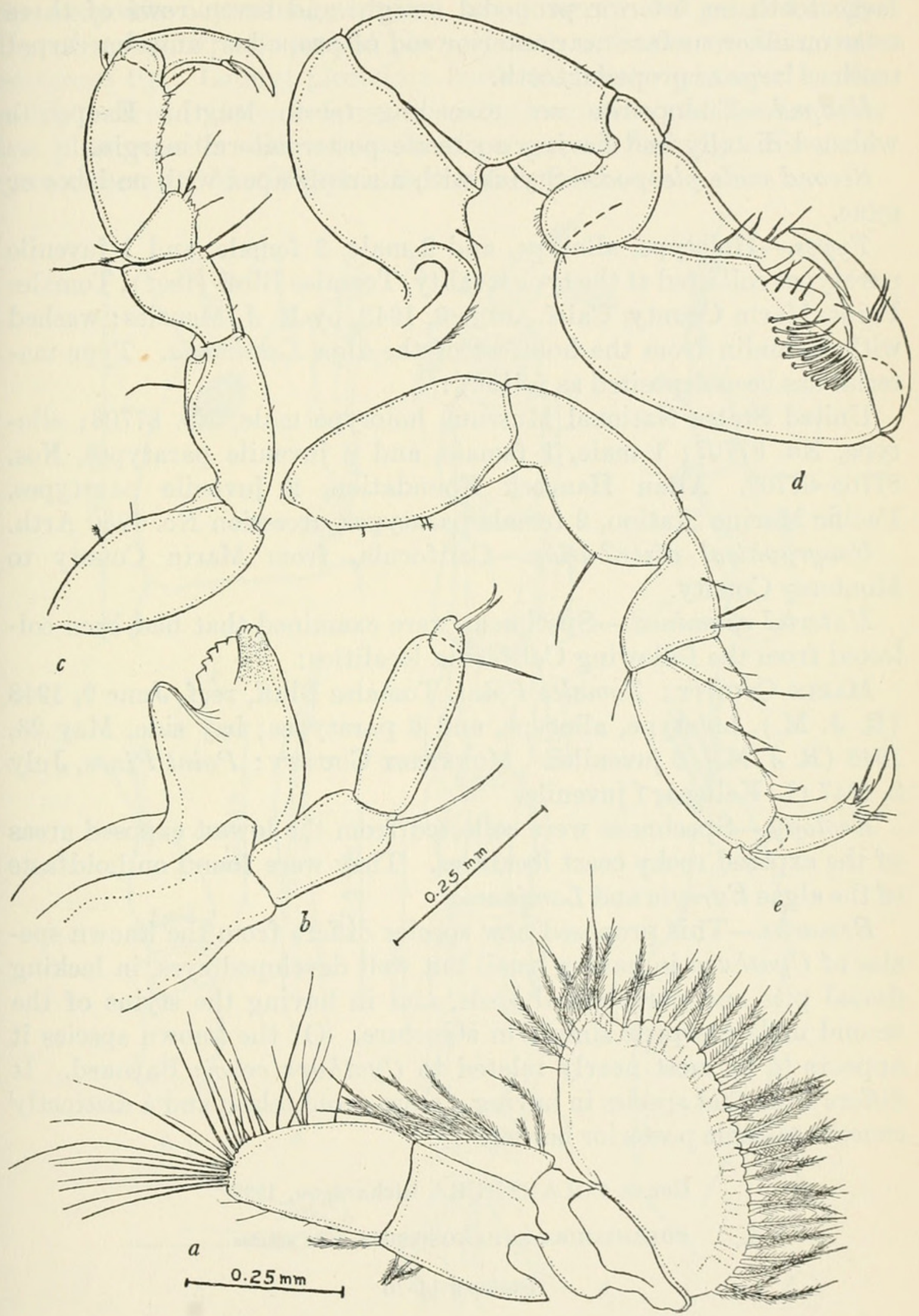

Figure 13.-Cyathura munda, new species: $a$, Uropod, dorsal view, holotype; $b$, right mandible, paratype; $c$, sixth peraeopod; $d$, first peraeopod; $e$, second peraeopod. (Magnification as indicated in scales; $c-e$ same as $a$.) 
joint about one-fourth the length of second and longest joint. Terminal joint with two setae at apex.

Peraeopods.-See figure 13, c-e. Gnathopod typical, bearing a large tooth on inferior propodal margin and seven rows of three setae on inner surface near anterior end of propodus; anterior carpal tooth as large as propodal tooth.

Uropod.-Endopodite not exceeding telson length. Exopodite widened distally and having a sinuate posterolateral margin.

Second male pleopod.-Stylus with a simple apex with no lobes or setae.

Types.-Holotype, allotype, and 2 male, 3 female, and 1 juvenile paratypes collected at the type locality, Tomales Bluff (reef), Tomales Point, Marin County, Calif., June 9, 1948, by R. J. Menzies; washed with formalin from the holdfast of the alga Laminaria. Type material has been deposited as follows:

United States National Museum, holotype male, No. 87706; allotype, No. 87707; 1 male, 1 female, and 2 juvenile paratypes, Nos. 87708-87709. Allan Hancock Foundation, 2 juvenile paratypes. Pacific Marine Station, 2 female paratypes, accession No. 1250 Arth.

Geographical distribution.-California, from Marin County to Monterey County.

Material examined.-Specimens were examined that had been collected from the following California localities:

Marin County: Tomales Point, Tomales Bluff, reef, June 9, 1948 (R. J. M.), holotype, allotype, and 6 paratypes; bay side, May 23, 1948 (R. J. M.), 2 juveniles. Monterey County : Point Pinos, July 3, 1947 (L. Kellen), 1 juvenile.

Ecology.-Specimens were collected from the lowest exposed areas of the exposed rocky coast localities. They were found on holdfasts of the algae Egregia and Laminaria.

Remarks.-This proposed new species differs from the known species of Cyathura in having small but well developed eyes, in lacking dorsal pits and dorsolateral keels, and in having the stylus of the second male pleopods simple in structure. Of the known species it appears to be most nearly related to Cyathura crucis Barnard. It differs from that species in having a more ovoid telson and a distinctly concave telsonic posterior border.

Genus COLANTHURA Richardson, 1902

COLANTHURA SQUAMOSISSIMA, new species

Figures 14-16

Holotype.-Male, length $4.5 \mathrm{~mm}$., width at widest part of second peraeon somite $0.4 \mathrm{~mm}$.

Allotype.-Ovigerous female, length $5.2 \mathrm{~mm}$., width $0.5 \mathrm{~mm}$. 
Diagnosis.-Rostral process very slightly exceeding forward extent of anterolateral angles. Eyes large, composed of about 14 ocelli. Endopodite of uropod extending to or very slightly beyond telson tip; exopodite not so long as telson, being narrow and pointed at tip. Tip of stylus of male second pleopod with a simple, swollen, nonsetiferous tip. Lateral pleotelson borders smooth; posterior border widely convex. Seventh peraeon somite narrower and shorter than first pleon somite. Seventh pair of peraeopods lacking. No statocysts observed. Maxilliped with one free joint.
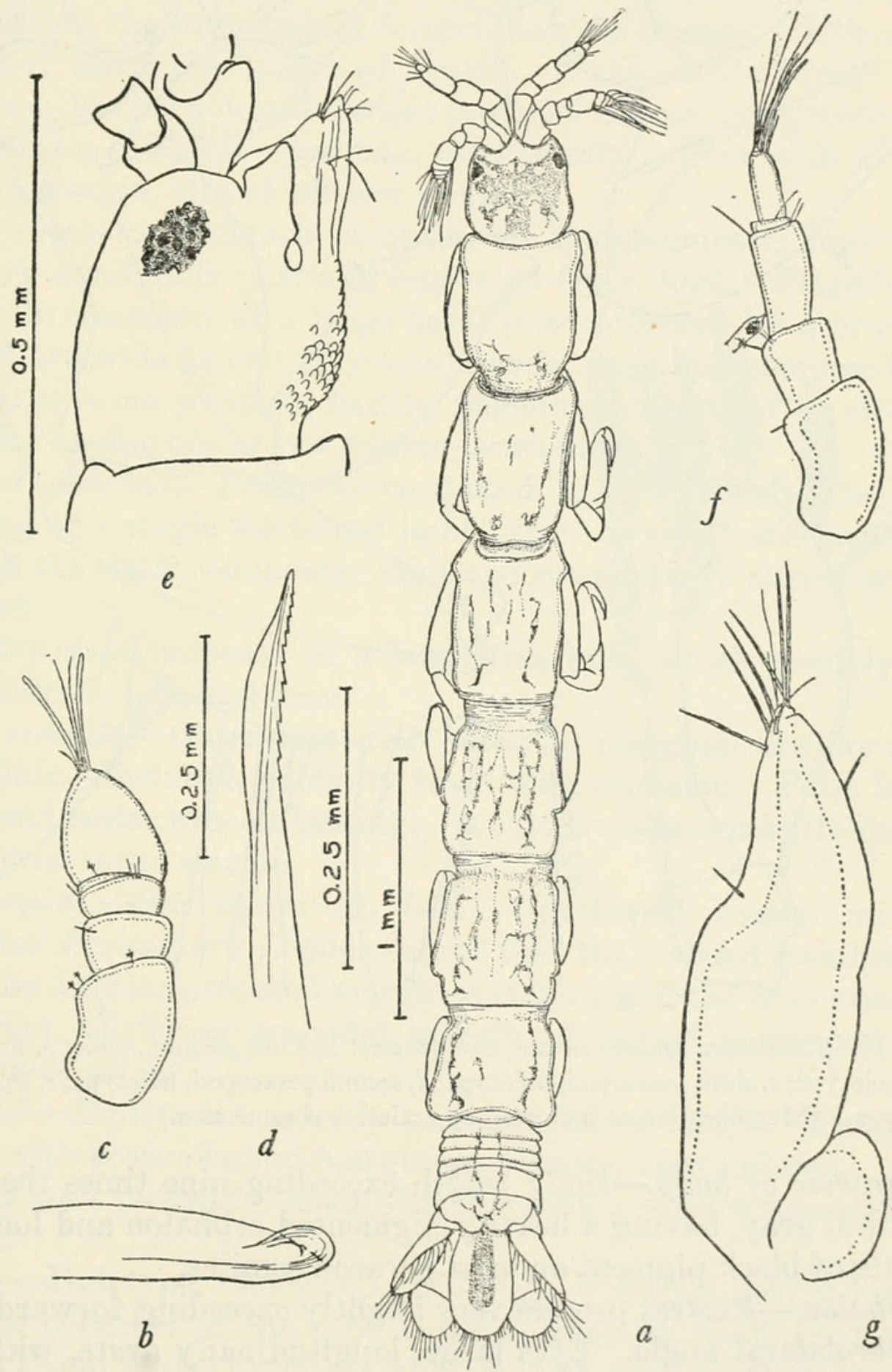

Figure 14.-Colanthura squamosissima, new species: $a$, Holotype, male; $b$, tip of stylus of second male pleopod; $c$, first antenna, young male paratype; $d$, first maxilla, holotype; $e$, lateral view of cephalon, holotype; $f$, first antenna, allotype; $g$, maxilliped, left, holotype. (Magnification as indicated by scales: $d$ and $g$ same as $b ; f$ same as $c$.) 


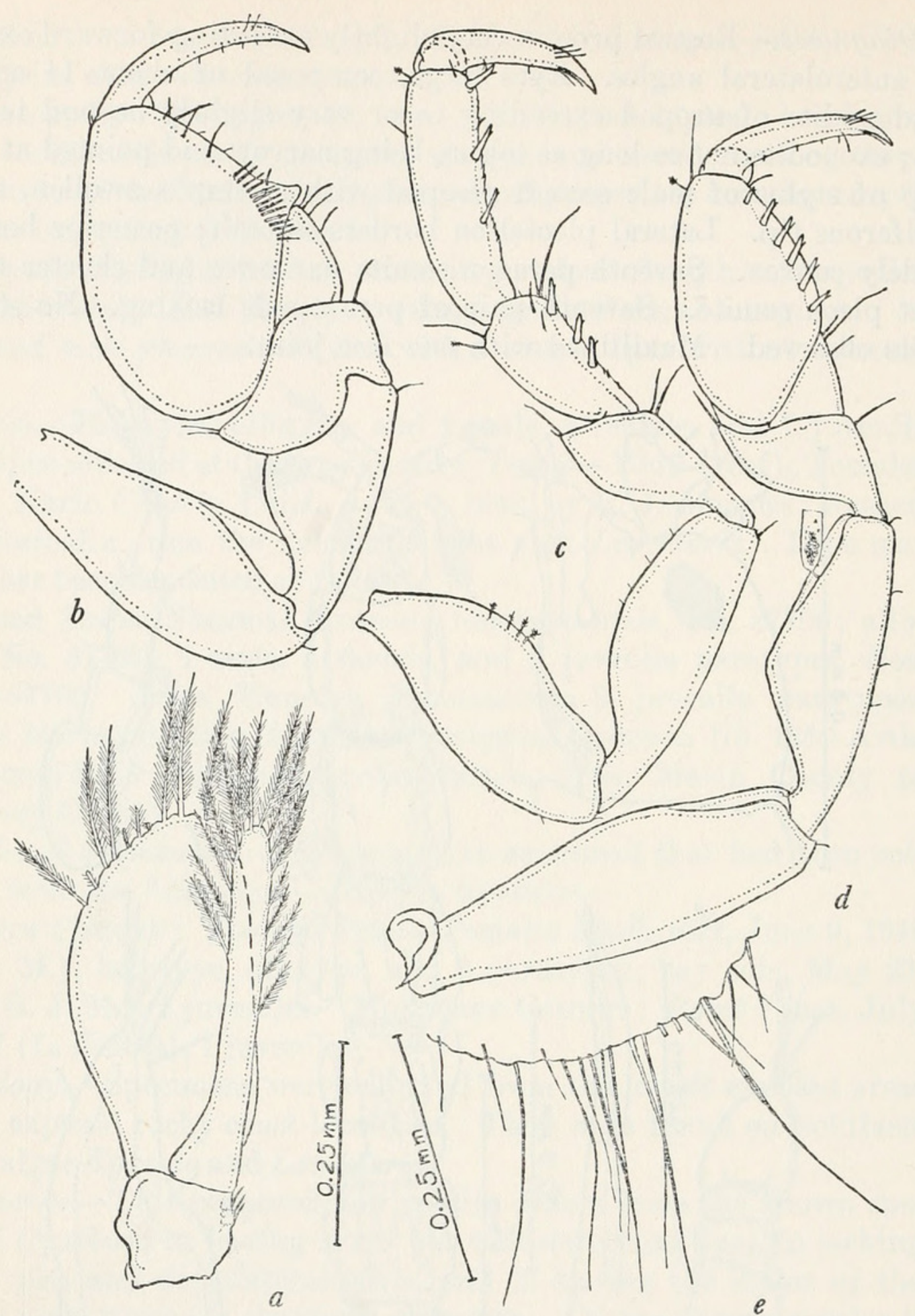

Figure 15.-Colanthura squamosissima, new species: $a$, First pleopod, male; $b$, first peraeopod, holotype; $c$, sixth peraeopod, holotype; $d$, second peraeopod, holotype; $e$, tip of telson, holotype. (Magnification as indicated by scales: $b-d$ same as $a$.)

Character of body.-Body length exceeding nine times the width. Body dull gray, having a heavily pigmented cephalon and longitudinal lines of black pigment on most peraeon somites.

Cephalon.-Rostral process very slightly exceeding forward extent of anterolateral angle. Eyes large, longitudinally ovate, with about 14 ocelli. Ocular lobe in lateral view with a very slightly produced 
blunt apex. Ventral surface of cephalon posterior to oral area covered with conspicuous large scales.

Peraeon.-First five somites similar in size. Sixth somite shorter than fifth. Seventh somite one-seventh the length of sixth somite and having only a crescentic dorsal area visible in dorsal view behind the sixth somite. Second and third somites with an anterior dorsal concavity for the reception of the posterior borders of the first and second somites respectively.

Pleon.-Demarcation of somites visible dorsally. First four somites similar, the first slightly longer than the others. Fifth somite about four times the length of fourth. Sixth somite firmly fused with telson, having a dorsal median posterior concavity indicating the line of fusion. Telson spatulate, apex evenly convex with a finely crenulate margin, lateral borders smooth.

First antenna.-Peduncle composed of four segments; fourth segment very small, only partially separated from third. Flagellum in adult male composed of a large basal joint followed by a brushlike series of five wide joints; in juvenile male, flagellum composed of a single large ovoid joint; in female, flagellum consists of an elongate basal joint having one or two minute joints at tip.

Second antenna.-Peduncle composed of six joints. Flagellum consisting of a single setiferous joint, which is about one-fourth the length of the sixth peduncular joint and considerably narrower than that joint.

Maxilliped.-Composed of a large free joint which possibly possesses a minute terminal joint.

First maxilla.-Outer lobe with about 12 marginal sawlike teeth. Mandible.-Reduced, partially fused with cephalon. Palp, lacina, incisor, and molar process lacking. A thin transparent knifelike lobe is present on inner margin.

Peraeopods.-See figure 15, $b-d$. Gnathopod similar to that figured for Paranthura elegans except that the striated membranous lobe of the inferior propodal margin is lacking and the setal armature is different. Inferior propodal margin of second peraeopod with six 2-pointed setae.

Uropod.-Endopodite scarcely exceeding telson length. Exopodite narrow, with posterolateral margin not sinuate, apex pointed.

Second male pleopod.-Apex of stylus with a swollen nonsetiferous lobe.

Types.-Holotype, allotype, and 6 male, 6 female, and 2 juvenile paratypes collected at the type locality, Tomales Bluff (bay side), Tomales Point, Marin County, Calif., May 23, 1948, by R. J. Menzies; washed with formalin from the holdfast of the alga Macrocystis. Type material has been deposited as follows: 
United States National Museum, holotype male, No. 87712; allotype, No. 87713; 2 male and 1 female paratypes, No. 87714. Allan Hancock Foundation, 2 male and 2 female paratypes. Pacific Marine Station, 2 male, 4 female, and 1 juvenile paratypes, accession No. 1243 Arth.

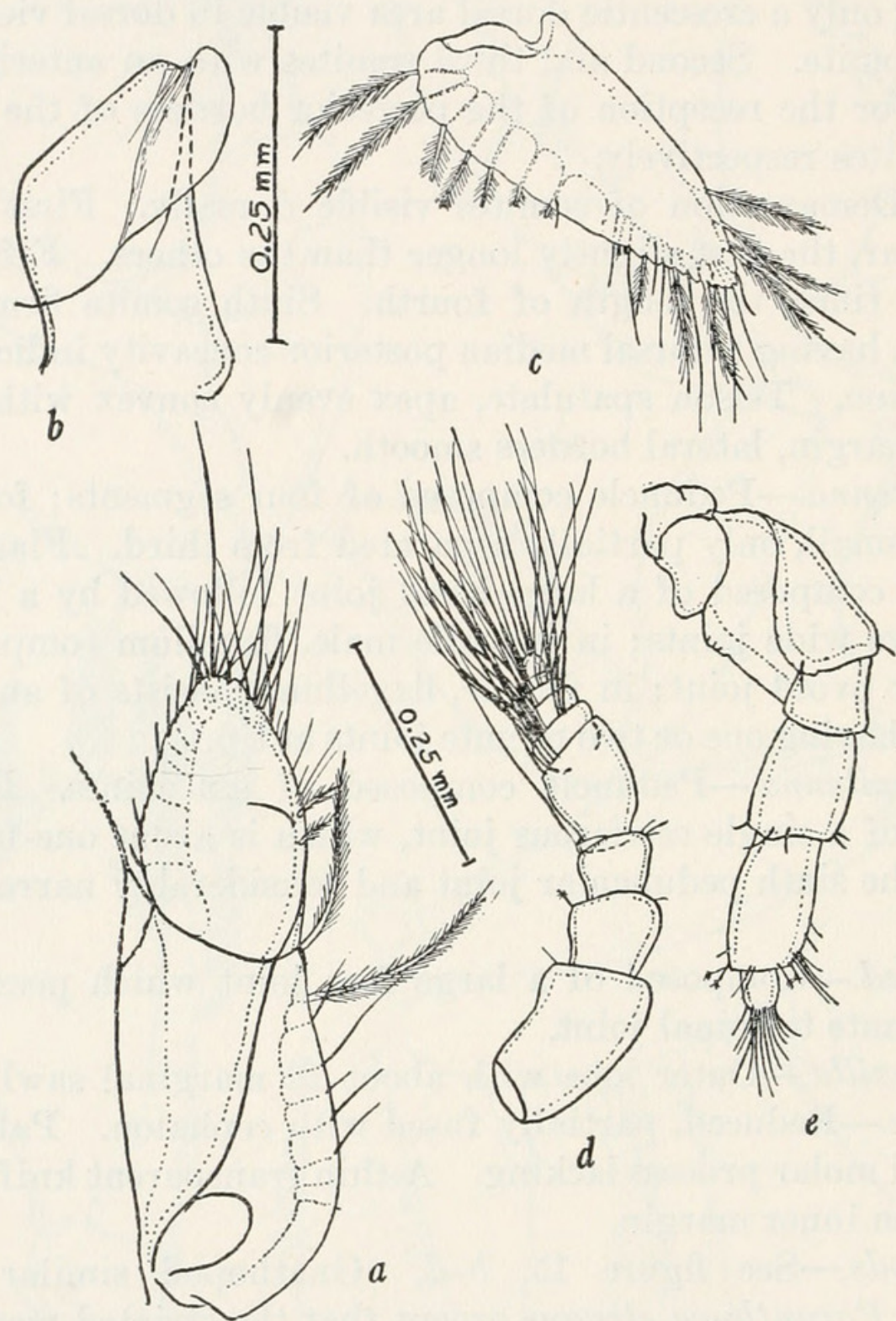

Figure 16.-Colanthura squamosissima, new species: $a$, Endopodite of uropod, dorsal view, holotype; $b$, mandible, male paratype; $c$, exopodite of uropod, dorsal view, holotype; $d$, first antenna, holotype; $e$, second antenna, holotype. (Magnification as indicated by scales: $c-e$ same as a.)

Geographical distribution.-Known only from the type locality. Material examined.--The above-listed types only.

Remarles.-This proposed new species differs from the only other known species, Colanthura tenuis Richardson, in having a last peraeon somite, which is shorter than the first pleon somite and a pronounced pointed projection at the inner proximal angle of the propodal joint of the gnathopod. In $C$. tenuis the seventh peraeon somite is longer than the first pleon somite, and no projection is evident on the propodal joint of the gnathopod. 


\section{Family ASTACILLIDAE}

Only one species of this family, Astacilla californica Boone (1918, pp. 600-601, pl. 89, fig. 1), has been previously reported from California. Boone's species was collected at Venice, Calif., and is based on a single adult female. The new species described herein was collected by Joel W. Hedgpeth, and it is with considerable pleasure that I name it after a man who has contributed so much to the study of marine science in America. The species appears to be rare, at least intertidally, in that a prior year of collecting failed to yield a single specimen. As far as I know this is the first record of an Idarcturus species from the Northern Hemisphere.

\section{Genus IDARCTURUS Barnard, 1914}

\section{IDARCTURUS HEDGPETHI, new species}

Figures 17,18

Holotype.-Ovigerous female, length $1.4 \mathrm{~mm}$., width at widest part of second peraeon somite $0.9 \mathrm{~mm}$.

Diagnosis.-Eyes lateral and bulging. Cephalon with two large spines on dorsum above eyes. First peraeon somite fused with cephalon, line of fusion indicated dorsally by a shallow tranverse grcove. Peraeon somites 1 to 7 with large triangulate anterolateral extensions, those of somites 6 and 7 appearing more lateral than anterolateral; somites 4 to 6 with large acute posterolateral spines; dorsal surface of posterior areas of somites 2 to 7 with a transverse row of four huge spines. Pleotelson composed of a single somite; each lateral margin with two large, angulate spines; posterior margin produced, apex blunt; dorsal surface near anterior end with two large, dorsally directed spines. Spinelike epimeral plates present on somites 3 and 4 , those of somite 4 visible in dorsal view. Palp of second antenna with a 3 -jointed flagellum, last joint with a large terminal claw. Maxilliped with two coupling hooks; palp with five segments. First peraeopod concealed from lateral view by lateral extensions of cephalon and first peraeon somite; claw lacking on distal joint.

Character of body.-Animal elongate, cream colored, body with huge spines, eyes black.

Cephalon.-Eyes bulging laterally. Anterior border deeply concave, with a minute median projection. Dorsal surface above eyes with two large laterally compressed spines. Lateral extensions of united cephalon and first peraeon somite conceal mouth parts and first peraeopod from lateral view.

Peraeon.-First somite fused with cephalon, line of fusion indicated dorsally by a shallow transverse groove, each anterolateral 
angle with a large laterally directed spine. Second and third somites similar, each with triangulate anterolateral extensions and a transverse row of four large spines on dorsal surface. Fourth somite exceeding two times the length of third, having spination of third somite plus a single small spine on middorsal surface at posterior border; epimeral spine visible in dorsal view below anterolateral spine. Fifth and sixth somites similar to but narrower than third

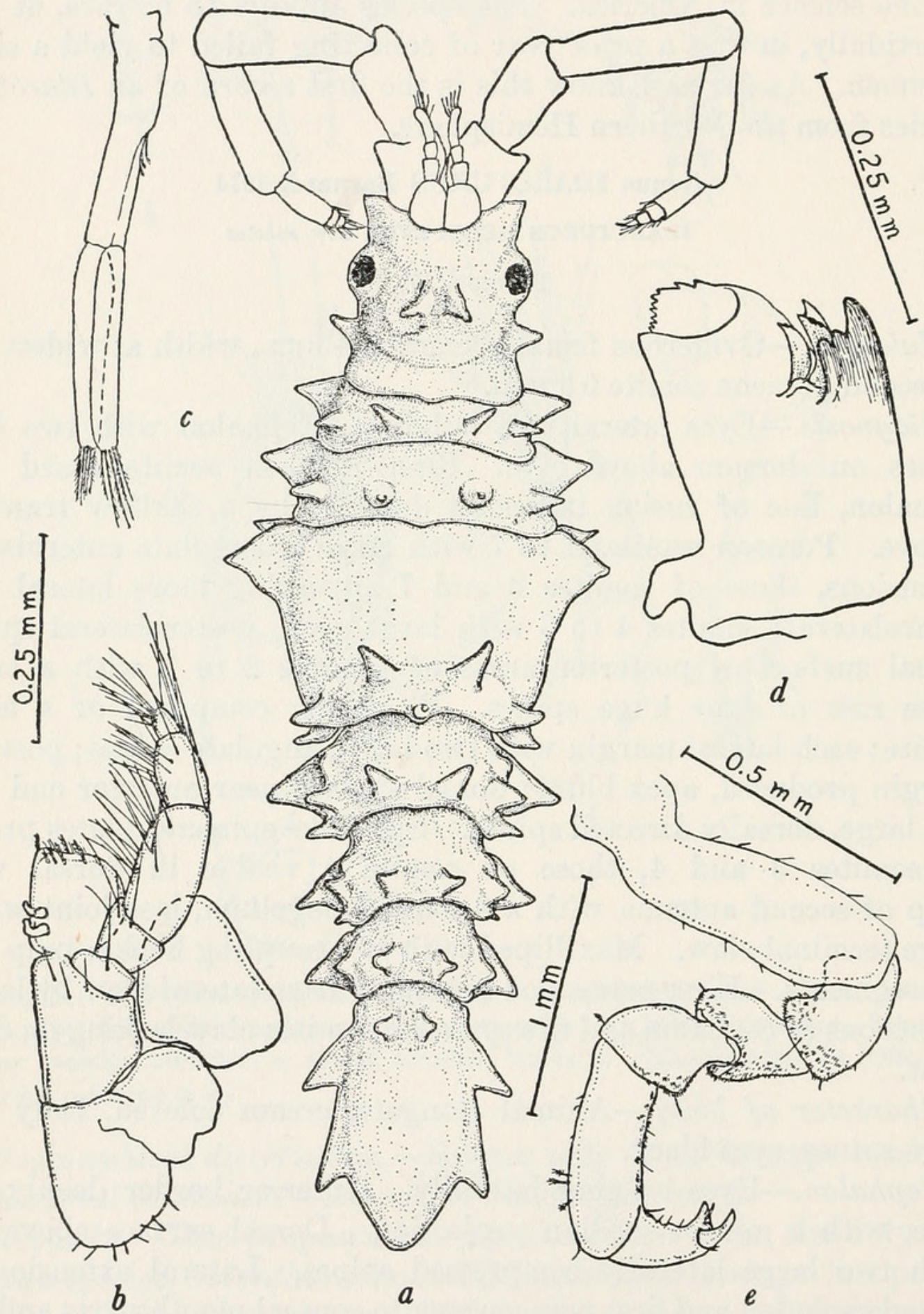

Figure 17.-Idarcturus hedgpethi, new species: $a$, Dorsal view, holotype; $b$, maxilliped; $c$, first pleopod, magnification not known; $d$, right mandible; $e$, fifth peraeopod. (Magnification as indicated by scales.) 

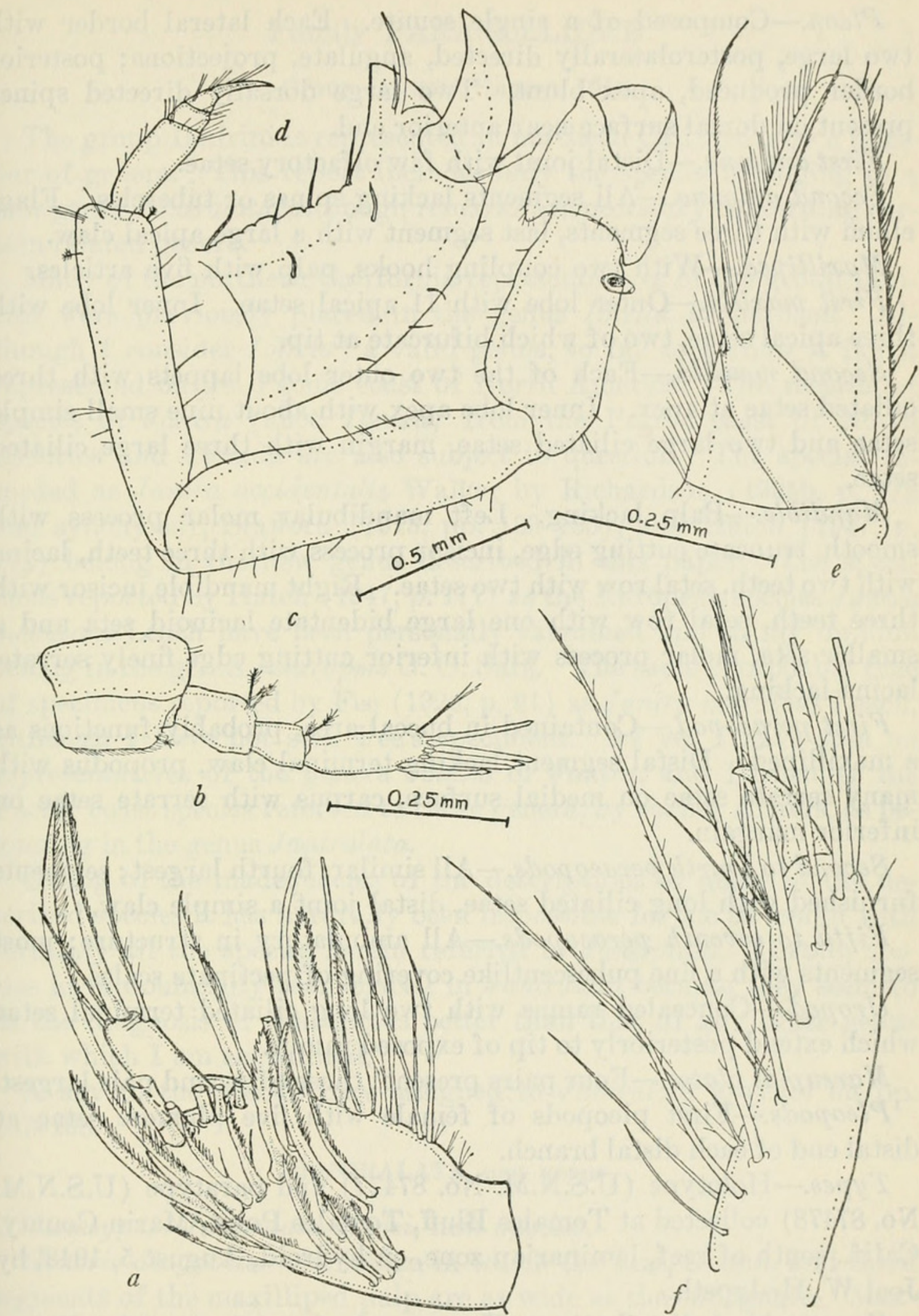

Figure 18.-Idarcturus hedgpethi, new species: $a$, Distal joints of first peraeopod; $b$, first antenna; $c$, second antenna; $d$, distal joints of fifth peraeopod; $e$, distal joints (rami of uropod, inner surface); $f$, distal joints of second peraeopod. (Magnification as indicated by scales: $a, d$, and $f$ same as $e$.)

and having a posterolateral spine and a lobe above lateral (anterolateral) spine in addition to the spines present on third somite. Seventh somite similar to sixth but lacking the lobe and posterolateral spine of that somite. 
Pleon.-Composed of a single somite. Each lateral border with two large, posterolaterally directed, angulate, projections; posterior border produced, apex blunt. Two large dorsally directed spines present on dorsal surface near anterior end.

First antenna.-Distal joint with few olfactory setae.

Second antenna.-All segments lacking spines or tubercles. Flagellum with three segments, last segment with a large apical claw.

Maxilliped.-With two coupling hooks, palp with five articles.

First maxilla.-Outer lobe with 11 apical setae. Inner lobe with three apical setae, two of which bifurcate at tip.

Second maxilla.-Each of the two outer lobe lappets with three ciliated setae at apex. Inner lobe apex with about nine small simple setae and two large ciliated setae, margin with three large ciliated setae.

Mandible.-Palp lacking. Left mandibular molar process with smooth, truncate cutting edge, incisor process with three teeth, lacina with two teeth, setal row with two setae. Right mandible incisor with three teeth, setal row with one large bidentate lacinoid seta and a smaller seta, molar process with inferior cutting edge finely serrate, lacina lacking.

First peraeopod:-Contained in buccal area, probably functions as a maxilliped. Distal segment lacking terminal claw, propodus with many serrate setae on medial surface, carpus with serrate setae on inferior margain.

Second to fourth peraeopods.-All similar, fourth largest; segments furnished with long ciliated setae, distal joint a simple claw.

Fifth to seventh peraeopods.-All ambulatory in structure; most segments with a fine pubescentlike covering of pectinate scales.

Uropod.-Concealed ramus with two long ciliated terminal setae which extend posteriorly to tip of exposed ramus.

Marsupial plates.-Four pairs present; those of second pair largest.

Pleopods.-First pleopods of female with five plumose setae at distal end of each distal branch.

Types.-Holotype (U.S.N.M. No. 87477) and paratype (U.S.N.M. No. 87478) collected at Tomales Bluff, Tomales Point, Marin County, Calif., south of reef, laminarian zone, on hydroid, August 5, 1948, by Joel W. Hedgpeth.

Geographical distribution.-Known only from the type locality.

Material examined.-Holotype and 1 female paratype.

Remarks.-This species differs from Idarcturus platysoma, Barnard, the genotype of Idarcturus, in having large body spines, which the genotype lacks. 


\section{Family PARASELLIDAE}

\section{Group IANIRINI Hansen, 1916}

The group Ianirini is represented in northern California by a number of genera. This report includes only the species belonging to a new genus Janiralata, although remarks are necessary concerning certain related genera.

Many of the northern California representatives of the group Ianirini were previously placed in the genus Iolella Richardson. Although I consider Iolella ${ }^{1}$ a valid genus, so far as I know it is not represented on the Pacific coast of North America. The records of species of Janira (auct. Ianira) from the Pacific coast of North America and Canada are also subject to question. The species recorded as Janira occidentalis Walker by Richardson (1905b, p. 472 and synonyms), Stafford (1913, pp. 183-185), and Hatch (1947, p. 172) belong in the new genus described in this paper. The specimens reported by Hatch $(1947$, p. 171) as the European species Janira maculosa Leach have been personally examined and in my opinion belong in the genus Ianiropsis G. O. Sars. The same is probably true of specimens reported by Fee (1926, p. 21) as Janira maculosa Leach, although I have not seen Fee's specimens. As yet I have seen no representatives of the genera Iolella or Janira, and I consider the Pacific coast species referred to those genera, by earlier writers, as belonging in the genus Janiralata.

Owing to the inadequacies of the descriptions of many of the described species it has naturally been impossible for me to assign with certainly all the species herein referred to Janiralata. Certain species have doubtfully been placed in Janiralata because they seem to fit the diagnosis of that genus better than that of any other genus with which I am acquainted.

A key to the species here assigned to Janiralata appears on pp. $137-138$.

\section{JANIRALATA, new genus}

Genotype.-Janiralata davisi, new species.

Generic diagnosis.-Janiridae in which the first, second, and third segments of the maxilliped palp are as wide as the endognath. Maxilliped with two or three coupling hooks. Dorsal surface of body lacking lobes or spinelike lobes. Epimera ${ }^{2}$ distinct on somites 2-7 and visible in dorsal view. Eyes present, dorsal but near lateral margins. Second antenna with a conspicuous antennal scale. First male pleopods with tips laterally expanded as in Ianiropsis, but

${ }^{1}$ See "Remarks Concerning Hansen's Concept of Janira Leach" on p. 138 of this paper.

2 Those of first peraeon somite frequently indistinct. 
bearing a setiferous projection on distal margin near medial border of each sympodite. Second male pleopod with a styliform proximal endopodite branch and a lamellar, somewhat rectangular, exopodite whose caudal end is blunt and setiferous. Uropods 2-branched, exceeding one-half the pleotelson length; inner branch as long as or longer than the outer branch. Female operculum widely ovate, with a small median concavity on posterior border. Mandibular molar process with an expanded, truncated, toothed, setiferous tip; palp 3 -jointed and bearing on distal third of second joint along medial margin two large denticulate setae and a diagonal row of similar but smaller setae on outer surface; last mandibular palp segment very much twisted at tip. Inferior border of proximal third of first peraeopod propodus with a number of subequal serrations. Carpal joint of first peraeopod swollen and beset with many 2-pointed setae on inferior margin; dactylus with two claws. Dactyls of other peraeopods with three claws. Pleon composed of a short anterior segment and a wide shieldlike pleotelson.

This genus appears to be intermediate between Iolella and Ianiropsis. It resembles Ianiropsis in having dorsally visible epimeral plates on peraeon somites 2-7. It resembles Iolella in that most of the species have the lateral peraeon margins produced into lappets. It differs from both genera in having a series of serrations on the inferior border of the proximal third of the propodus of the first peraeopod and in having a row of small denticulate setae between two large setae on the distal third of the second joint of the mandibular palp.

The generic characteristics given in the above generic diagnosis are omitted from the specific descriptions given for the new species described in this paper.

JANIRALATA DAVISI, new species

Figures 19, 20

Holotype-Male, length $3.5 \mathrm{~mm}$., width at widest part of second peraeon somite $2.0 \mathrm{~mm}$.

Allotype.-Length $4.7 \mathrm{~mm}$., width $2.4 \mathrm{~mm}$.

Diagnosis.-Cephalon anterior border with a very short triangulate median lobe and two triangulate anterolateral expansions. Eyes dorsal, separated from lateral border a distance equal to their widths. Lobate lateral extensions of the first three peraeon somites separated from one another by a narrow V-shaped slit. Pleotelson posterior margin with rounded posterolateral areas and a short, rounded median lobe. Lateral areas of head and body setiferous. Maxilliped with three coupling hooks. First male pleopods with acute laterally ex- 
panded tips; distal margins very slightly irregular except for the elevations that characterize the first male pleopods of species belonging to the genus.

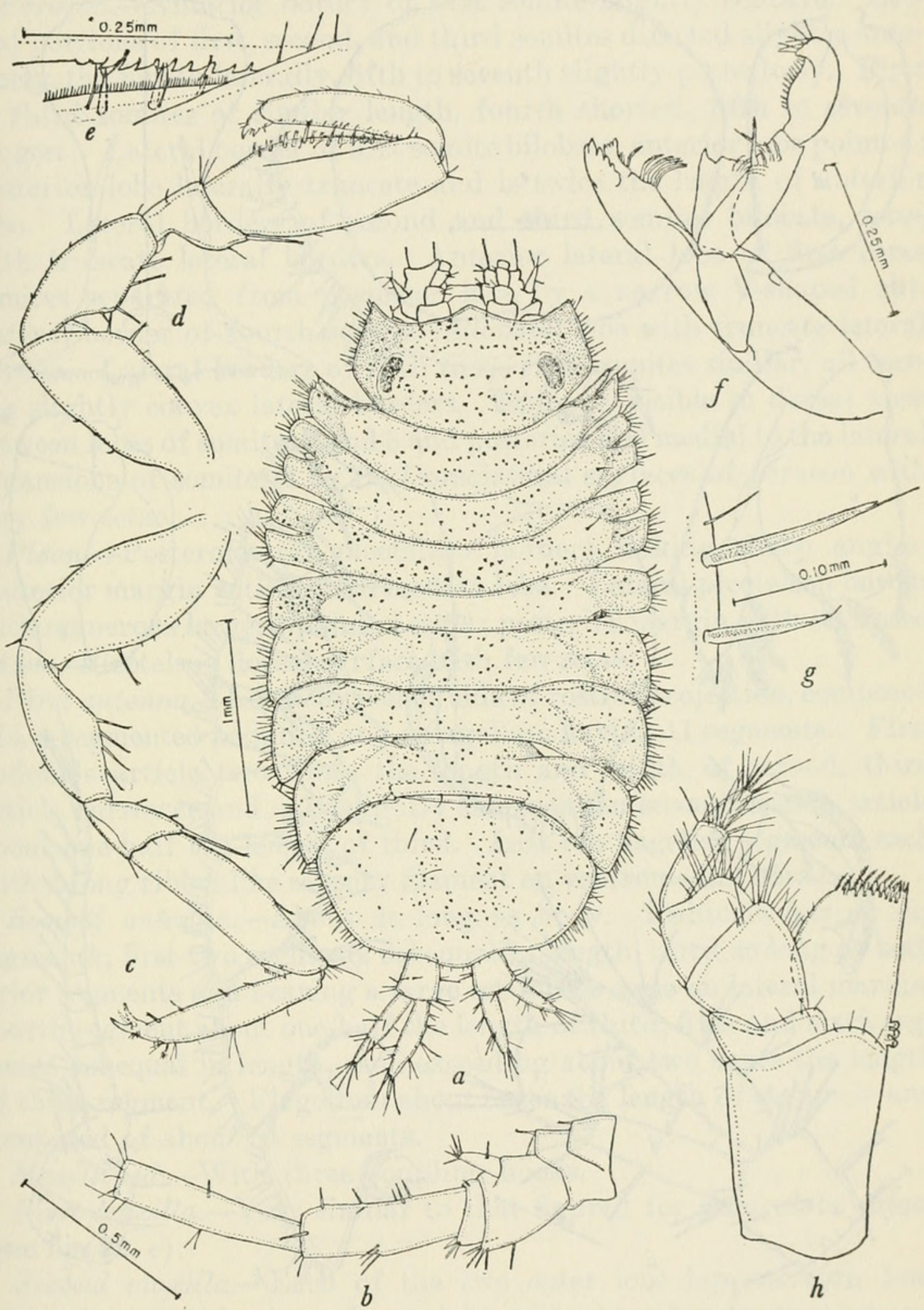

Figure 19.- Janiralata davisi, new species: $a$, Holotype, dorsal view; $b$, second antenna, paratype; $c$, seventh peraeopod, left, holotype; $d$, first peraeopod, left, holotype; e, proximal third of propodal inferior margin, first peraeopod, holotype; $f$, mandible, left, paratype; $g$, setae of lateral border of cephalon, holotype; $h$, right maxilliped, holotype. (Magnification as indicated by scales: $c$ and $d$ same as $b ; h$ same as $f$.) 
Character of body.-Lateral border of cephalon and body with a fringe of 2-pointed setae. Animal wide and flattened, having numerous, scattered, black chromatophores.

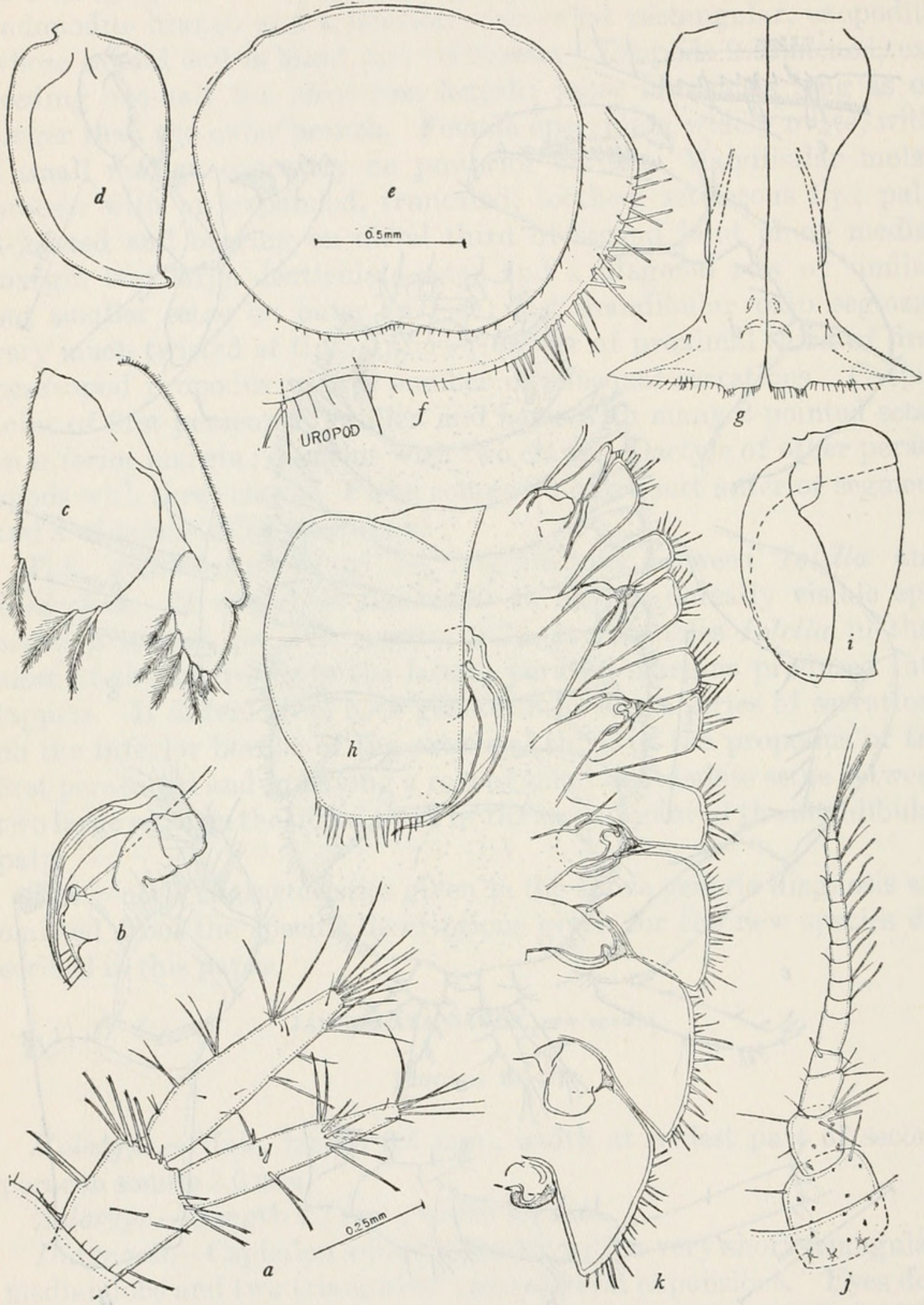

Figure 20.-Janiralata davisi, new species: $a$, Left uropod, holotype; $b$, inner view of right second male pleopod, paratype; $c$, right third pleopod, paratype male; $d$, right fifth pleopod, paratype male; $e$, female operaculum, allotype; $f$, pleotelson right border, holotype; $g$, first pleopods, paratype male; $h$, outer view of right second male pleopod, paratype; $i$, right fourth pleopod, paratype male; $j$, first antenna, holotype; $k$, right lateral border, ventral view of holotype, stippled areas of epimera visible in dorsal view. (Magnification as indicated by scales: $b-d$ and $f-j$ same as $a ; k$ same as $e$.) 
Cephalon.-Wider than long, anteriorly with a very short triangulate median lobe and two triangulate anterolateral expansions. Eyes dorsal, separated from lateral border a distance equal to their widths.

Peraeon.-Anterior border of first somite slightly concave. Lateral portions of first, second, and third somites directed slightly anteriorly, the fourth laterally, fifth to seventh slightly posteriorly. First to third somites of similar length, fourth shortest, fifth to seventh longest. Lateral border of first somite bilobate, anterior lobe pointed; posterior lobe laterally truncate and is twice the length of anterior lobe. Lateral borders of second and third somites bilobate, lobes with truncate lateral borders. Anterior lateral lobe of first three somites separated from posterior lobe by a narrow V-shaped slit. Lateral border of fourth somite unilobate, lobe with truncate lateral border. Lateral borders of fifth to seventh somites similar, all having slightly convex lateral borders. Epimera visible in dorsal view between lobes of somites 2 and 3 and posterior and medial to the lateral expansions of somites 4 to 7 . Dorsolateral surfaces of peraeon with very few setae.

Pleon.-Posterolateral pleotelson borders lacking sharp angles; posterior margin with a small median lobe. Lateral pleotelson border with numerous large, 2-pointed setae; posterior margin with scattered setae. Pleotelson dorsal surface with few setae.

First antenna.-Located on each side of rostral projection, composed of a 4-segmented peduncle and a flagellum having 11 segments. First peduncle article two times the length and width of second, third article narrower and only slightly shorter than second, fourth article about one-half the length of third. Last ten flagellar segments each with a long ribbonlike sensory filament on ventromedial border.

Second antenna.-About as long as body. Peduncle having six segments; first two segments subequal in length, third as long as both prior segments and bearing a large setiferous scale on lateral margin, fourth segment about one-half the length of third, fifth and sixth segments subequal in length, each exceeding about two times the length of third segment. Flagellum about twice the length of peduncle and composed of about 54 segments.

Maxilliped.-With three coupling hooks.

First maxilla.-Very similar to that figured for Janiralata rajata (see fig. 22,e).

Second maxilla.-Each of the two outer lobe lappets with four denticulate apical setae. Inner lobe with about ten large setae and many fine setae on margin and apex.

Mandible.-Left mandible with incisive part having five teeth; lacina with four teeth; setal row with one seta at base of lacina and a row of six setae proximal to the solitary one; molar process with expanded, denticulate tip bearing six narrow setae; palp composed of 
three articles, the second of which is the longest. Distal third of inner margin of second palp article with two long denticulate setae between which is an oblique row of three similar but smaller setae. Left mandible similar to right except that it lacks a lacina and bears 11 setae in setal row.

First peraeopod.-Propodus with a row of about 9 subequal serrations on proximal third of inferior margin. Carpus expanded, bearing 15 2-pointed setae along inferior margin.

Other peraeopods.-In general structure similar to first peraeopods except that the carpal segment is not expanded.

Uropods.-Not exceeding pleotelson length; each composed of a peduncle and two branches. Peduncular segment widest at distal end, branches subequal in length. In allotype the peduncular segment is about as long as inner branch and is more setose than that figured for holotype.

Pleopods.-First male pleopods with lateral distal angles acute, distal margins very slightly irregular save for the setiferous elevations that characterize species of this genus. Second male pleopod with outer branch somewhat rectangular, having a truncate, setiferous distal margin; inner branches with a curved, styliform proximal branch extending beyond the tip of outer branch and located midway between distal and proximal margins and a short thick distal branch articulating slightly proximal to the mediodistal angle of outer plate. Third male pleopod with a narrow 2 -jointed exopodite, distal joint bearing six plumose setae; endopodite roughly rectangular, with three plumose setae on distal margin. Fourth male pleopod with fleshy singlejointed branches that lack setae.

Types.-Holotype, allotype, and 1 male and 5 female (1 ovigerous) paratypes collected at the type locality, Carmel Cove, Monterey County, Calif., July 6, 1947, by John Davis; specimens found on undersurface of submerged rock in zone 4 of the intertidal. ${ }^{3}$ Type material deposited as follows:

United States National Museum, holotype, No. 87479; allotype, No. 87480; 1 male and 2 female paratypes, No. 87481. Allan Hancock Foundation, 1 female paratype. Pacific Marine Station, 2 female paratypes, accession No. 1218 Arth.

JANIRALATA RAJATA, new species

Figures 21, 22

Holotype.-Male, length $4.0 \mathrm{~mm}$., width at widest part of second peraeon somite $1.0 \mathrm{~mm}$.

Diagnosis.-Cephalon with an exceedingly short, evenly rounded

\footnotetext{
${ }^{3}$ Specimens donated to writer by Dr. Frank A. Pitelka, Zoology Department, University of California.
} 
rostrum; anterolateral border evenly rounded, with two setae. Eyes large, almost touching lateral margins. Lateral lobate extensions of second and third peraeon somites separated from one another by a distance exceeding three times the length of largest lobe. Pleotelson
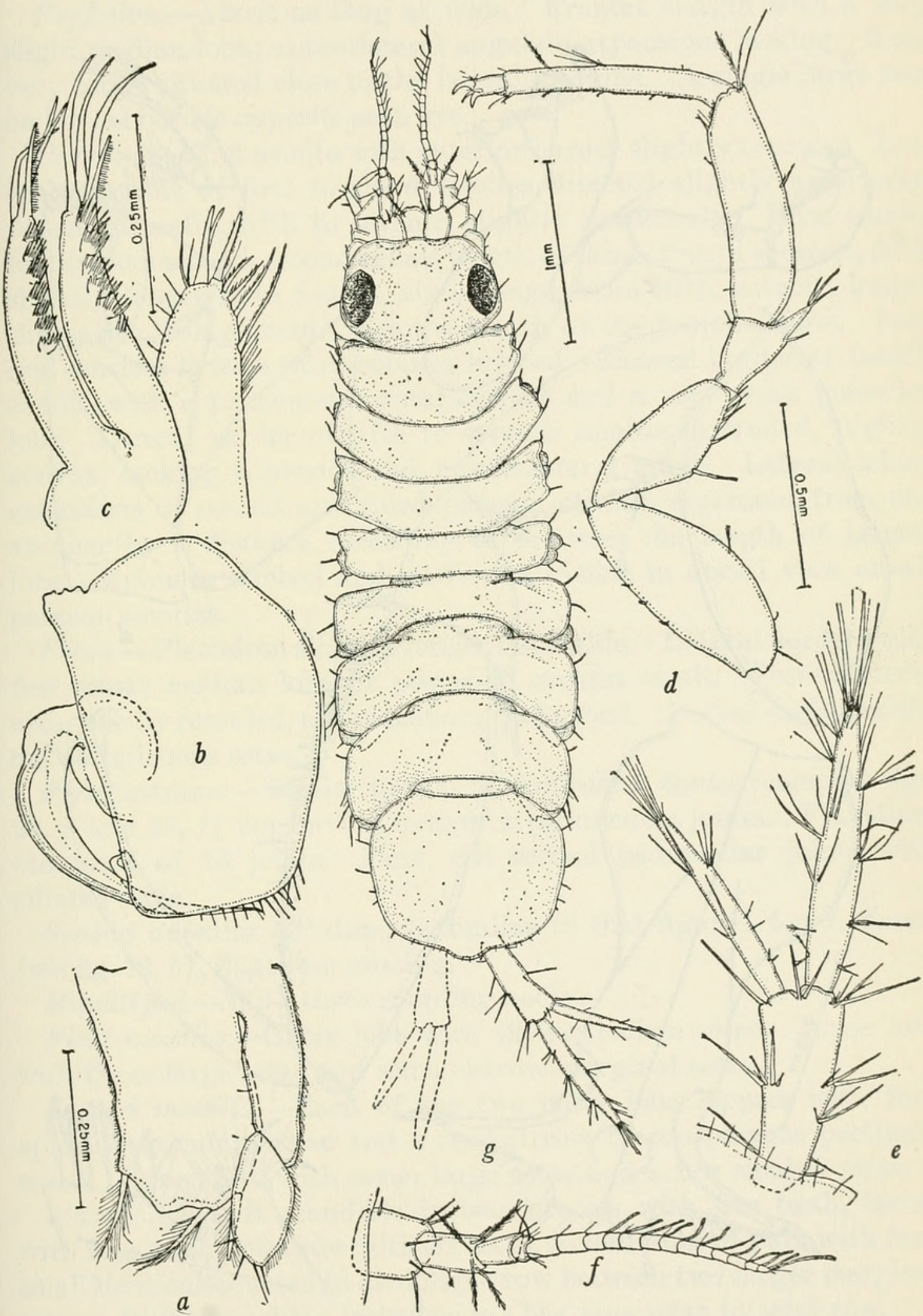

Figure 21.-Janiralata rajata, new species, holotype male: $a$, Third pleopod, left; $b$, second pleopod, left; $c$, second maxilla, right; $d$, sixth peraeopod, right; $e$, uropod, right; $f$, first antenna, right; $g$, holotype. (Magnification as indicated by scales: $b$ same as $a$; e and $f$ same as $d$.) 
with posterolateral areas evenly rounded; posterior margin with a slight median convexity. Lateral cephalon areas each with a single seta; body and pleotelson with few setae on lateral borders. Lateral tip of each first male pleopod twisted to form a groove.

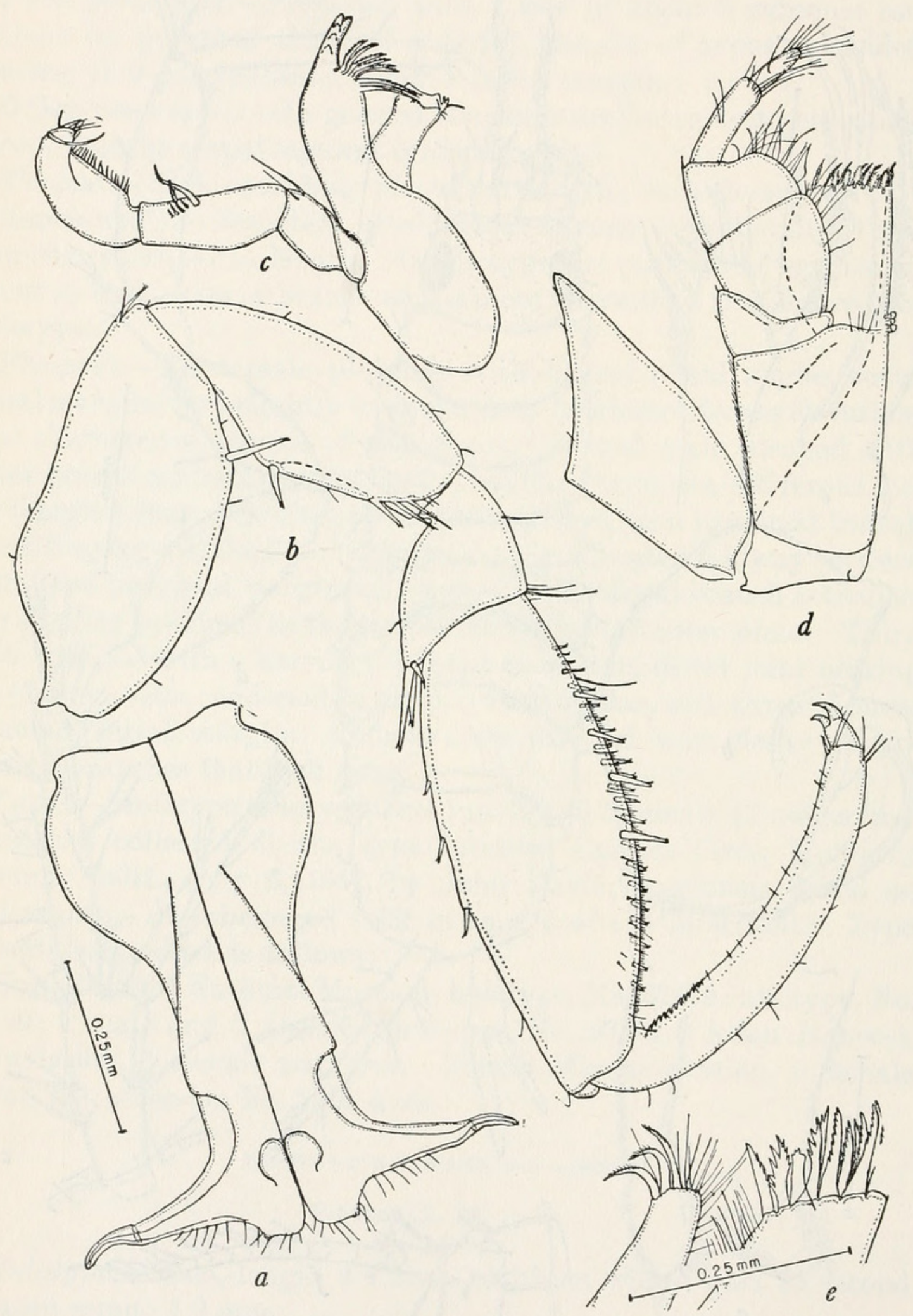

Figure 22.-Janiralata rajata, new species; holotype male: $a$, First pleopod, inner surface; $b$, first peraeopod, right; $c$, mandible, right; $d$, maxilliped, right; $e$, first maxilla, right. (Magnification as indicated by scales: $b-d$ same as $a$.) 
Character of body.-Body elongate, narrow, and flattened. Lateral borders of cephalon and body with few setae. White in color, no black chromatophores evident. Lateral peraeon areas not expanded into conspicuous lappets.

Cephalon.-About as long as wide. Frontal margin with a very slight median lobe; anterolateral angulate expansions lacking. Eyes very large, situated close to the lateral margins. A single large seta on lateral border opposite each eye.

Peraeon.-First somite with anterior border slightly concave. Lateral portions of first to third somites directed slightly anteriorly, fourth laterally, fifth to seventh slightly posteriorly. First somite longer than second, second equals length of third, fourth shortest, fifth slightly longer than fourth, sixth longer than fifth, seventh longer than sixth, being about twice the length of the fourth somite. Lateral borders first to third somites bilobed. Lateral border of fourth somite with a pronounced anterior lobe and a very weak posterior lobe. Lateral border of fifth to seventh somites expanded, slightly convex, lacking a pronounced posterolateral angle. Lateral lobate extensions of second and third peraeon somites separated from one another by a distance exceeding three times the length of largest lobe. Epimera bilobed and setiferous, visible in dorsal view on all peraeon somites.

Pleon.-Pleotelson slightly longer than wide. Lateral borders with few setae; median lobe of posterior margin small. Posterolateral areas evenly rounded, no evident angles formed. Dorsal surface without conspicuous setae.

First antenna.-Similar to that of Janiralata davisi (compare figs. $20, j$, and $21, f$ ) but having narrower peduncular joints. Flagellum composed of 13 joints. First and second peduncular joints with ciliated setae.

Second antenna.-Peduncule similar to that figured for $J$. davisi (see fig. 19, $b$ ), flagellum missing.

Maxilliped.-With three coupling hooks.

First maxilla.-Outer lobe with 12 denticulate setae. Inner lobe with three large setae and some narrow marginal setae.

Second maxilla.-Each of the two outer lobe lappets with four apical denticulate setae and a medial row of conspicuous pectinate scales. Inner lobe with seven large setae and a few smaller setae.

Mandible.-Left mandible incisor process with five teeth, lacina with four teeth, setal row with six setae, second joint of palp with four smali denticulate setae in an oblique row between two larger marginal setae. Right mandible lacks lacina; has nine setae in setal row.

First peraeopod.-Similar to that figured for $J$. davisi (compare figs. $19, d$, and $22, b$ ) except that the carpal inferior margin has 26 2-pointed setae. 
Uropods.-Greatly exceed pleotelson length.

Pleopods.-Lateral tip of each first male pleopod twisted to form a groove. Second and third male pleopods very similar to those figured for $J$. davisi (compare figs. $20, h, c$, with $21, b, a$ ).

Type-Holotype male (U. S. N. M. No. 43646) collected at Monterey Bay, Calif., date not given on label, by Harold Heath, from Raja binoculata egg, 20 fathoms.

Geographical distribution.-Known only from the type locality.

Remarks.-This specimen was identified by Dr. Harriet Richardson Searle as Janiropsis californica and was sent to me by Dr. Fenner A. Chace, Jr., curator of marine invertebrates, U. S. National Museum, as an example of that species. In my opinion this specimen could not possibly represent Janiropsis californica, inasmuch as the description applicable to this specimen differs much too greatly from the description of Janiropsis californica Richardson (Richardson, 1905b, p. 455, figs. 507-508). The types of J. californica are not to be found at the U. S. National Museum, according to Dr. Chace. There are some specimens in the Pacific Marine Station Museum collections that agree in most essential respects with the description and figures of $J$. californica as given by Dr. Richardson (op. cit.). The specimens were collected as ectocommensals from the isopod Sphaeroma pentodon Richardson and possibly belong in the genus Iais; however, I cannot agree with Dr. Th. Monod's supposition (Nordenstam, 1933, p. 179) that Janiropsis californica is a synonym of Iais pubescens (Dana).

JANIRALATA SOLASTERI (Hatch)

Figures 23, $e, f ; 24$

Janira solasteri НАтсH, 1947, p. 172, pl. 14, figs. 158-160.

Diagnosis.-Cephalon with an elongate, pointed rostrum; anterolateral borders each with a wide angulate projection. Eyes dorsal, situated a considerable distance away from the lateral borders of cephalon. Lateral lobate extensions of second and third peraeon somites separated from one another a distance exceeding twice the length of anterior lobe. Pleotelson with angulate, medially recurved posterolateral projections and a medially unilobate posterior margin that does not extend posteriorly beyond the limits of the posterolateral angles. Structure of male first pleopod not known.

\section{SUPPLEMENTARY DESCRIPTIVE NOTES}

Cephalon.-Wider than long, with a prominent pointed rostrum, two mediolateral lobes, and a setiferous angulate anterolateral extension on each side of cephalon. Eyes dorsal, bulging, located a considerable distance from lateral margins

Peraeon.-Similar to that figured for J. occidentalis (compare figs. 
23, $a$, and 24,a), except that the epimeral lobe of the first somite is not visible in dorsal view between the lateral lobate extensions of that somite.

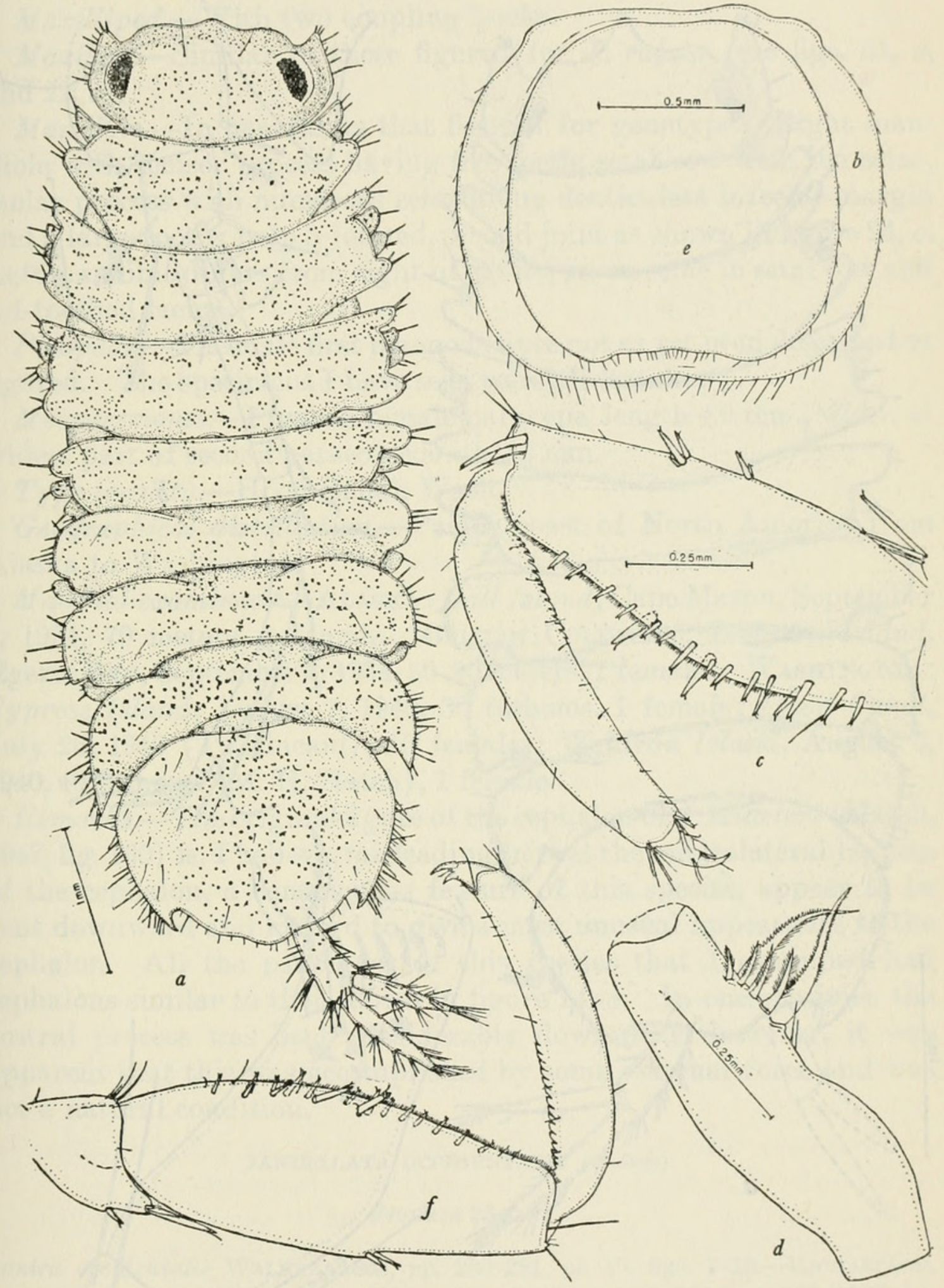

Figure 23.- $a-d$, Janiralata occidentalis (Walker): $a$, Ovigerous female hypotype; $b$, operculum, female hypotype; $c$, distal joints of first peraeopod, female hypotype; $d$, second joint of mandibular palp of right mandible, female hypotype. e, $f$, Janiralata solasteri (Hatch), female paratype: $e$, operculum; $f$, distal joints of first peraeopod. (Magnification as indicated by scales.) 
Pleotelson.-Similar to that figured for $J$. occidentalis (compare figs. $23, a$, and $24, a$ ), except that the posterolateral spinelike projections are more pronounced and exceed very slightly the posterior ex-

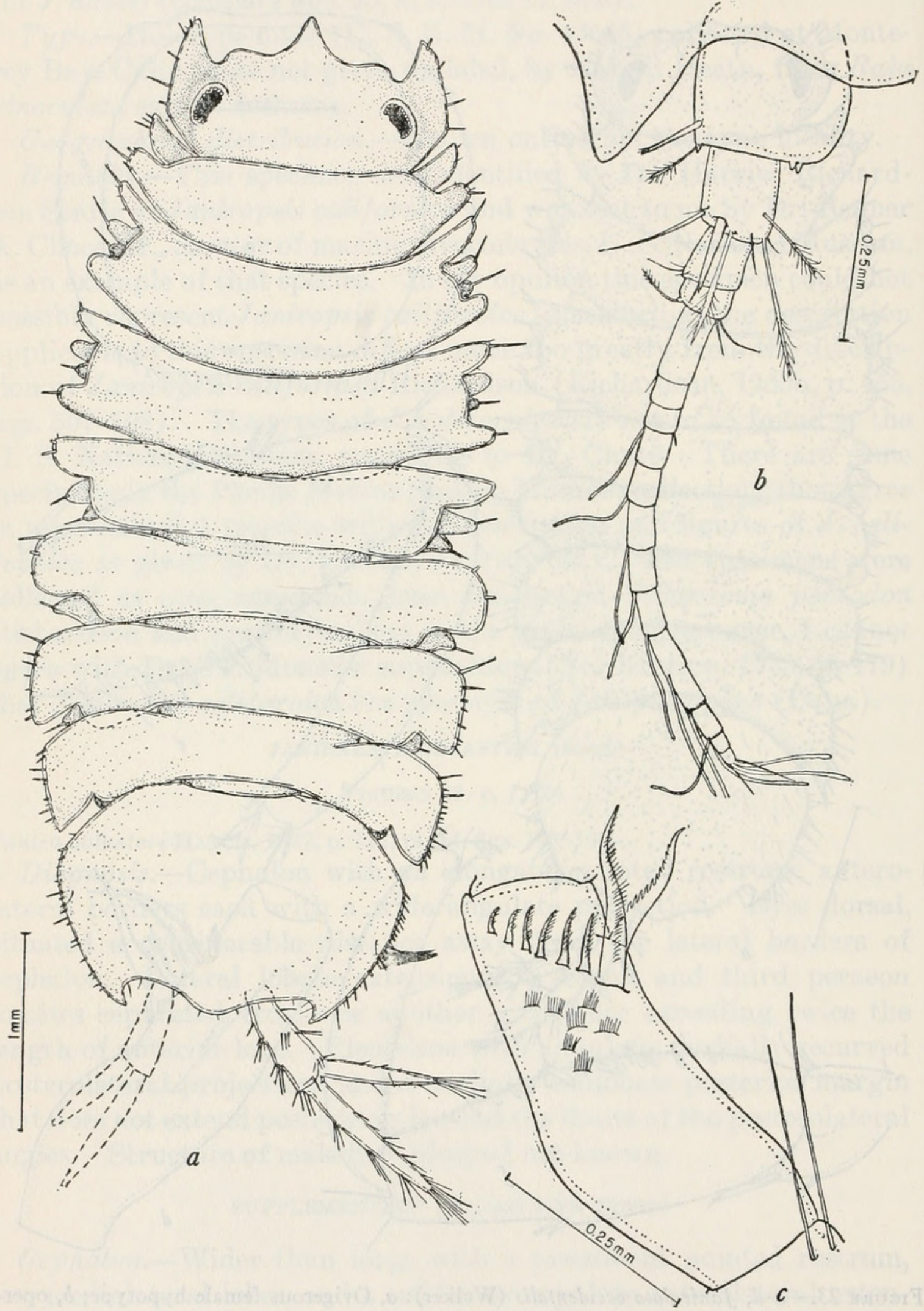

Figure 24.-Janiralata solasteri (Hatch): $a$, Female paratype; $b$, left first antenna, female paratype; $c$, second joint of mandibular palp of right mandible, female paratype. (Magnification as indicated by scales.) 
tent of the median lobe of the posterior margin and that the posterior margin has concave lateral areas and a single convex median lobe.

First antenna.-Similar to that of $J$. davisi (compare figs. 19, $b$, and $24, b)$.

Maxilliped.-With two coupling hooks.

Maxillae.-Similar to those figured for J. rajata (see figs. 21, c, and $22, e)$.

Mandible.-In general as that figured for genotype. Right mandible with incisor process having five teeth, setal row with ten setae, molar process with numerous setae along denticulate inferior margin and a large tooth; palp 3-jointed, second joint as shown in figure 24, $c$. Left mandible differs from right in having seven setae in setal row and a 4 -toothed lacina.

Pleopods.-The male first pleopods have not as yet been described or figured. The specimens I have seen were all females.

Measurements.-Figured female paratype, length $4.9 \mathrm{~mm}$., width at widest part of second peraeon somite $2.0 \mathrm{~mm}$.

Type locality.-Hood Canal, Wash.

Geographical distribution.-Pacific coast of North America from Alaska to Washington.

Material examined. ${ }^{4}$-Alaska : Dall Island, Cape Mazon, September 4, 1934, 70 meters, 1 female. British Colombia: Langara Island, Egeria Bay, September 3, 1934, 50-90 meters, 1 female. Washington : Cypress Island, August 7, 1940, 30 fathoms, 1 female; Hood Canal, July 26, 1940 (T. Kincaid), 10 females; Waldron Island, August 6, 1940, 40 fathoms (M. H. Hatch), 1 female.

Remarks.-The original figure of the cephalon of J. solasteri (Hatch, 1947, fig. 160) is, I believe, misleading in that the anterolateral lappets of the cephalon, a conspicuous feature of this species, appear to be bent downward and inward to give a most unusual appearance to the cephalon. All the paratypes of this species that I examined had cephalons similar to that shown in figure $24, a$. In one specimen the rostral process was bent considerably downward; however, it was apparent that this was accomplished by some external force and was not a natural condition.

\section{JANIRALATA OCCIDENTALIS (Walker)}

Figures 23, $a-d$

Janira occidentalis WALKer, 1898, pp. 280-281, pl. 15, figs. 7-10.-RichaRdSON, 1899a, p. 859 ; 1899b, p. 326 ; 1900, p. 300 ; 1904a, p. 224 ; 1904b, p. 667 ; 1905, pp. 472-473, figs. 526-528.-Stafford, 1913, pp. 183-185, fig. 7.-НатсH, 1947, p. 172 , pl. 111, figs. $35-36$.

- Paratype females kindly lent to the writer by Dr. Melville H. Hatch, Zoology Depart ment, University of Washington, Seattle, Wash. 
Diagnosis.-Cephalon anteriorly with a very short triangulate median projection and an angulate expansion at each anterolateral angle. Eyes dorsal, separated from lateral border by a distance equal to the width of one eye. Lobate lateral expansions of second and third peraeon somites separated from one another by a distance exceeding two times the length of anterior lobe. Pleotelson with spinelike, medially recurved, posterolateral projections and a slightly trilobate posterior margin whose medial lobe extends posteriorly beyond the posterior extent of the posterolateral angles. Body and pleotelson lateral areas setiferous. Male first pleopod structure not known.

\section{SUPPLEMENTARY DESCRIPTIVE NOTES}

Cephalon.-Wider than long, anteriorly with a small triangulate median lobe, two wide mediolateral lobes and an angulate setiferous projection at each anterolateral border. Eyes dorsal, bulging, located a distance equal to the width of an eye from lateral border.

Peraeon.-First somite with a trilobate lateral border, the medial and perhaps the anterior lobes representing epimeral lobes. Lateral borders of sixth and seventh somites with a small posteromedial lobe. Epimera bilobed, anterior lobe the larger.

Pleotelson.-Pleotelson with a medially recurved spinelike projection at each posterolateral angle; posterior margin trilobate, median lobe exceeding the posterior extent of posterolateral angles. Lateral borders setiferous.

Maxilliped.-With three coupling hooks.

Mandible.-Right mandible with incisor process having 5 teeth, setal row with 15 setae, molar process with 10 setae along denticulate inferior margin and a large tooth; palp 3-jointed, second joint as shown in figure $23, d$. Left mandible differing from right in having a 4-toothed lacina and nine setae in setal row.

Peraeopods.-First peraeopod propodus with a row of 15 serrations on inferior proximal margin; carpus expanded, with eighteen 2pointed setae along inferior margin.

Uropods.-As long as pleotelson, inner branch slightly longer than outer branch.

Pleopods.-The male first pleopods have not as yet been described or figured. The specimens I have seen were females.

Measurements.-Figured ovigerous female hypotype, length 5.4 mm., width at widest part of second peraeon somite $2.1 \mathrm{~mm}$.

Type locality.-Puget Sound, Wash.

Geographical distribution.-Pacific coast of North America, from Turn Rock, Turn Island, San Juan County, Wash., to Laguna Beach, Orange County, Calif. 
Material examined.-W Ashington ${ }^{5}$ : San Juan County, Turn Rock, Turn Island, July 4 and 7, 1940, under rock at low tide (F. A. Pitelka), 2 females, one ovigerous. California ${ }^{6}$ : Monterey County, Point Pinos, July 4, 1947, under submerged rock (John Davis), 1 ovigerous female.

\section{OTHER SPECIES ASSIGNED TO JANIRALATA}

In addition to the species already discussed, several others appear from their descriptions also to belong in the genus Janiralata. The species for which the generic assignments are fairly certain are Iolella alascensis Benedict, 1905 (Richardson, 1905b, p. 464), Tole holmesi Richardson, 1905 (as Iolella in Richardson, 1905b, p. 465) and Iolella sarsi Richardson, $1905 \mathrm{~b}$, p. 467. The following species I doubtfully refer to Janiralata: Ianthe erostrata Richardson, 1899 (as Iolella erostrata in Richardson, 1905b, p. 465), Ianthe triangulata Richardson, 1899 (as Iolella in Richardson 1905b, p. 462), and Janira soldatovi Gurjanova, 1933, pp. 81-82, 90.

In my opinion, Vanhöffen's placement of the species alascensis, triangulata, erostrata, holmesi, and sarsi in Beddard's genus Janthopsis is less warranted than the placement, by other authors, of those species in Janira or even in Iolella. Iolella (=Ianthe) and Janira both differ from Janthopsis, as Beddard points out (Beddard, 1886, pp. 14-15), in having uropodal branches subequal in length to each other and to the basal or peduncular joint. In Janthopsis the basal joint exceeds twice the length of the longest uropodal branch. The male first pleopods appear, from the figures I have seen, to differ considerably from those figured for Janthopsis (Beddard, 1886, pl. 5, figs. 6, 7). Further differences do exist (see Nordenstam, 1933, pp. 180-183); however, it seems unnecessary to enumerate them here.

\section{A KEY TO THE SPECIES OF JANIRALATA}

$a^{1}$. Pleotelson with distinct medially recurved, spinelike posterolateral angles. $b^{1}$. Cephalon lateral margin with a deep incision_.. triangulata (Richardson)

$b^{2}$. Cephalon lateral margin entire.

$c^{1}$. Cephalon anterolateral angles bifurcating _-_-_. holmesi (Richardson)

$c^{2}$. Cephalon anterolateral areas blunt or angulate, not bifurcating.

$d^{1}$. Cephalon anterolateral areas blunt_ sarsi (Richardson)

$d^{2}$. Cephalon anterolateral areas angulate.

$e^{1}$. Cephalon with an elongate pointed rostral projection; spinelike posterolateral angles of pleotelson slightly exceeding the posterior extent of medial posterior pleotelson lobe------ solasteri (Hatch)

s Specimens lent to writer by Dr. Melville H. Hatch, Zoology Department, University of Washington, Seattle, Wash.

- Specimen lent to writer by Dr. Frank A. Pitelka, Zoology Department, University of California. 
$e^{2}$. Cephalon with a short triangulate rostrum; spinelike posterolateral angles of pleotelson not exceeding the posterior extent of medial posterior pleotelson lobe occidentalis (Walker)

$a^{2}$. Pleotelson posterolateral areas evenly curved, lacking distinct angles or spinelike processes.

$b^{\mathbf{1}}$. Cephalon lacking expanded anterolateral angles_..--- rajata, new species $b^{2}$. Cephalon with expanded anterolateral angles.

$c^{1}$. Cephalon rostral projection exceeding the anterior extent of anterolateral angles. alascensis (Benedict)

$c^{2}$. Cephalon with or without a small rostral projection which, if present, does not exceed the anterior extent of anterolateral angles.

$d^{1}$. Posterior pleotelson border consisting of three equally produced prominent lobes.

$e^{1}$. Dorsal surface of pleotelson with a row of setae above insertion of each uropod ${ }^{7}$ soldatovi (Gurjanova)

$e^{2}$. Dorsal surface of pleotelson lacking a row of setae above insertion of each uropod erostrata (Richardson)

$d^{2}$. Posterior pleotelson border with a single median lobe.

davisi, new species

\section{REMARKS CONCERNING HANSEN'S CONCEPT OF JANIRA LEACH}

Hansen (1916, p. 21) canceled Iolella Richardson, 1905 (also known as Ianthe, Tole, and Iole) simply by considering the genotype of Iolella, Ianthe speciosa Bovallius, a synonym of Ianira spinsosa Harger. Whether he was justified in this decision remains problematical. Richardson (1905b, p. 460) did not agree with Hansen in this respect and was severely criticized by Hansen $(1916$, p. 22) for this view. Hansen wrote, "But as she [Richardson] had not seen any specimen refered to $I$. speciosa and not any further material, the statement, ' $I$ find it [I. speciosa] distinct from $I$. spinosa', is of no value."

Since specimens, in particular the types, of neither species are available to me, I am unable to resolve this dispute. Assuming for the present that Richardson was correct and Hansen incorrect, then one must determine whether Iolella has any morphological characteristics that separate it from Ianira (auct. Janira). Hansen did not believe so and writes, "Iolella Richardson with its synonyms . . . can not be separated from Ianira in any natural way." In that respect I cannot agree with Hansen, and I feel that I can substantiate my belief, in part at least, with Hansen's own statements. Since Hansen considered Ianthe speciosa Bovallius (the genotype of Iolella) a synonym of Ianira spinosa Harger any generic remarks he would have concerning $I$. spinosa probably also apply to $I$. speciosa. $\mathrm{He}$ writes of I. spinosa Harger, "Epimeral processes are completely

\footnotetext{
${ }^{7}$ If this is an error (Gurjanova, 1933, p. 90, English translation), as it might possibly be, then I should, with little hesitation, consider $J$. soldatovi a synonym of J. erostrata. In $J$. erostrata and the other species of this genus the ventral surface of the pleotelson does have a row of setae anterior to the insertion of each uropod; however, Gurjanova definitely states that two rows of setae (=spines) are present on the dorsal pleotelson surface in $J$. soldatovi.
} 
wanting at the lateral lappets of the three anterior thoracic segments . . . ," and of Ianira maculosa Leach, the genotype of Ianira, he writes, "Epimeral plates developed at all thoracic segments." Such differences, in my opinion, certainly separate the two genera and in a very natural way, especially when they are reinforced by other morphological evidence. The male first pleopods of Iolella lacinata (G. O. Sars) differ considerably from those of Ianira maculosa Leach. Since the structure of the male first pleopods of Iolella spinosa (Harger) and $I$. speciosa Bovallius is not known, I cannot be certain that they are structurally similar to those of Iolella lacinata; however, the probability is good that they are similar. I. maculosa and its related species $I$. alta and $I$. tricornis lack elongate, pointed, posterolateral telsonic lappets, with structures as well developed on Iolella speciosa, I. spinosa, and I. lacinata. I believe that here, then, are other structural features separating the two groups of species. The total of the differences, in my opinion, makes it necessary that the groups of species as typified by Ianira maculosa, on the one hand, and Iolella speciosa, on the other hand, be generically separated from one another. The other problem exists, however; if Iolella speciosa is a synonym of Iolella spinosa, as Hansen asserts, then a genotype should be selected for the species resembling $I$. speciosa. Since I cannot at present settle the question with certainty, I arbitrarily accept Richardson's statement that the species in question are distinct from one another. Such an acceptance, with due regard to Dr. Hansen, does, of course, permit less change in the existing nomenclature and for that reason appears to be the more desirable alternative.

Group Munnini Hansen, 1916

Subgroup PleURogonirni ${ }^{8}$ Nordenstam, 1933

Genus PLEUROGONIUM G. O. Sars

PLEUROGONIUM CALIFORNIENSE, new species

Figures 25, 26

Holotype.-Male, length $1.25 \mathrm{~mm}$., width at widest part of second peraeon somite $0.8 \mathrm{~mm}$.

Allotype.-Length $1.1 \mathrm{~mm}$., width $0.6 \mathrm{~mm}$.

Diagnosis.-First peraeon somite exceeding twice the length of second, posterolateral edges evenly curved, lacking spines; anterolateral angles each with a large anterolaterally directed spine. Epimeral spines of second to sixth somites located at posterior angle of the epimeral plates. Pleotelson with a distinct constriction at anterior end and with smooth lateral borders beset with a few small setae.

${ }^{8}$ Considered by Nordenstam, p. 199 , to be a subgroup of Hansen's Munnini. 
Maxilliped with two coupling hooks. Apex of male first pleopods shorter than is usual for members of this genus.

Character of body.-Flattened with ovoid lateral outline. The most conspicuous features are the absence of chromatophores and eyes and the presence of very large epimeral spines. Body smooth on dorsal surface, lacking any conspicuous setae. Some microscopic setae are present especially at the borders of each somite.

Cephalon.-Wider than long. Anterior border triangulate with convex anterior portion of upper lip visible in dorsal view. Lateral borders occupied by the insertion of the first antennae. Eyes lacking, dorsolateral ovoid muscle insertions are evident in a position where they might be mistaken for eyes.

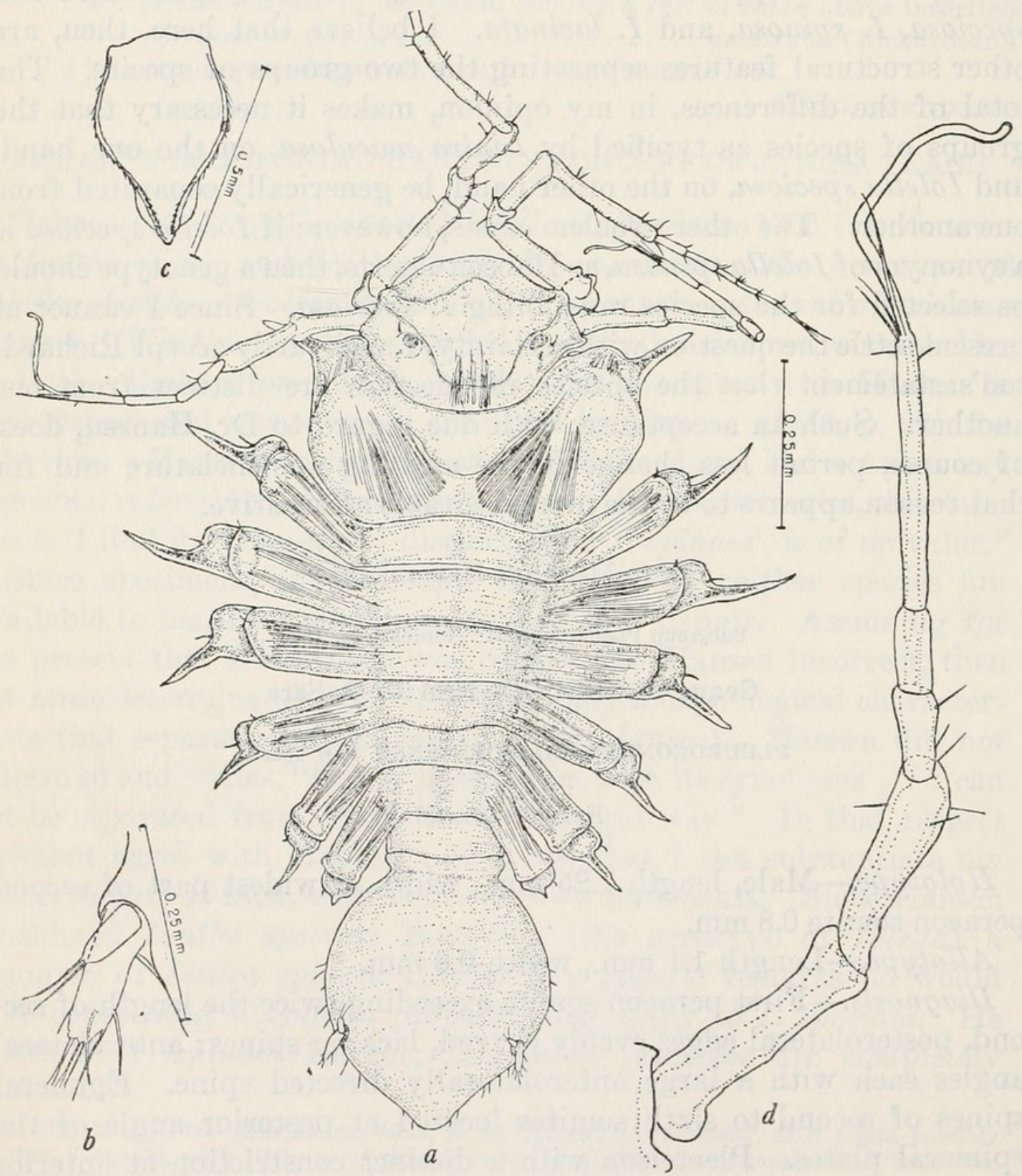

Figure 25.-Pleurogonium californiense, new species: $a$, Holotype male; $b$, left uropod, holotype; $c$, operculum, allotype; $d$, left first antenna, holotype. (Magnification as indicated by scales: $d$ same as $b$.) 


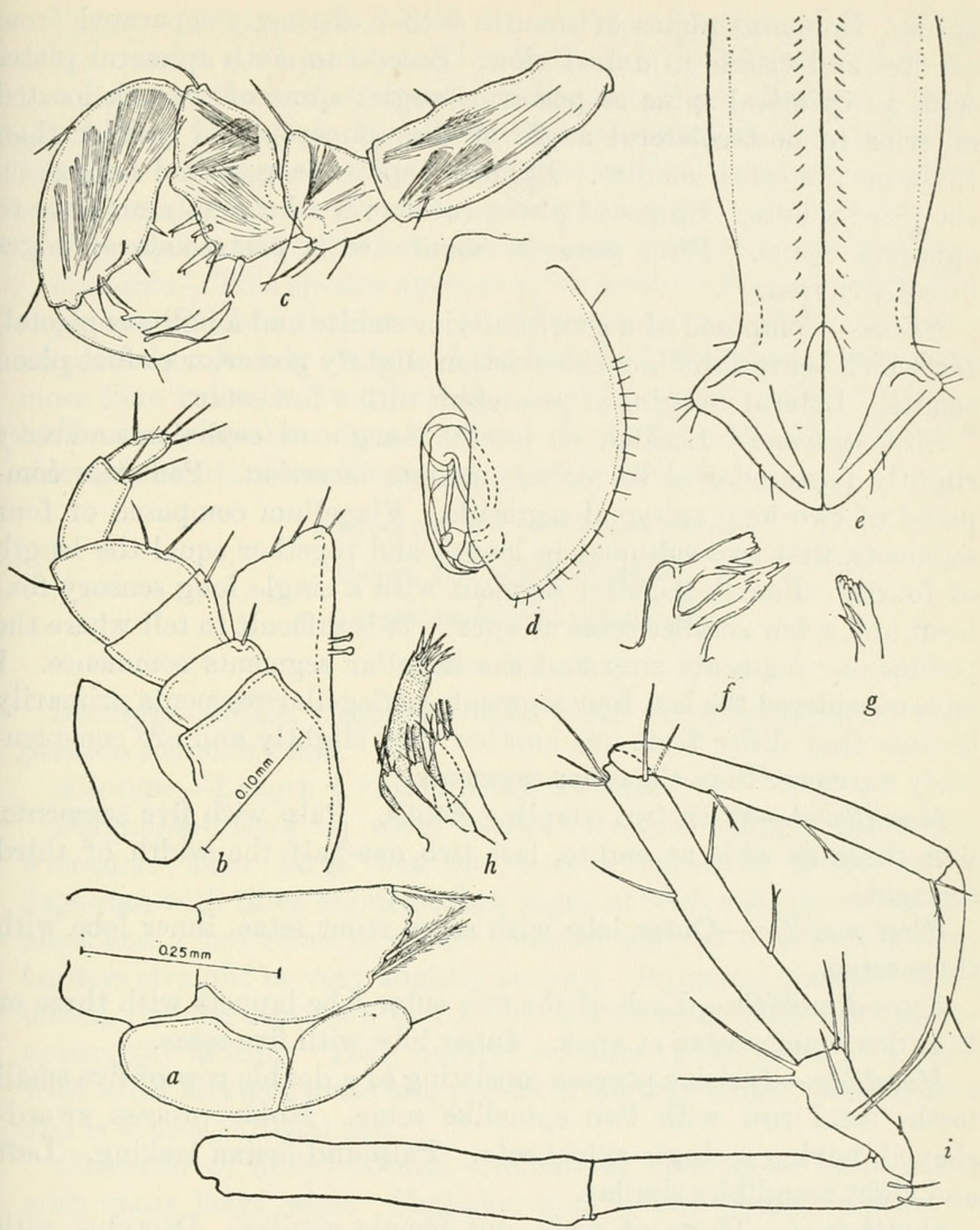

FigURE 26.-Pleurogonium californiense, new species: $a$, Left third pleopod, male paratype; $b$, maxilliped, male paratype; $c$, right gnathopod, holotype; $d$, left second pleopod, male paratype; $e$, male first pleopod, paratype; $f$, right mandible, male paratype; $g$, incisor process of left mandible, male paratype; $h$, right first and second maxillae, male paratype; $i$, right seventh peraeopod. (Magnification as indicated by scales: $c-e$ and $i$ same as $a$; $f-h$ same as $b$.)

Peraeon.-Lateral borders of first somite markedly anteriorly produced, those of somites 2 and 3 less so, that of somite 4 laterally directed, those of somites 5 to 7 posterolaterally directed. First somite exceeding twice the length of second somite, somites 2 to 7 short and subequal in length. Epimeral plate of first somite not separated from somite and bearing a long, narrow, anterolaterally directed epimeral 
spine. Epimeral plates of somites 2 to 7 distinctly separated from somites and visible in dorsal view. Second to sixth epimeral plates with an epimeral spine at posterior angle; spine of seventh located anterior to posterolateral angle of the epimeron and smaller than those on the other somites. Epimeral spines largest and longest on the third somite. Epimeral plates each with a large seta anterior to epimeral spine. First peraeon somite with posterolateral edges broadly curved.

Pleon-Composed of a short anterior somite and a bulbous pleotelson which bears a distinct constriction slightly posterior to first pleon somite. Lateral margins of pleotelson with a few setae.

First antenna.-Located on lateral margin of cephalon and very slightly posterodorsal to second antenna insertion. Peduncle composed of two long subequal segments. Flagellum composed of four segments, first two subequal in length and together equal the length of fourth. Fourth flagellar segment with a single long sensory filament and a few smaller setae at apex. It is difficult to tell where the peduncular segments stop and the flagellar segments commence. I have considered the last four segments as flagellar segments primarily because they differ from one another very slightly and are conspicuously narrower than the other segments.

Maxilliped.-With two coupling hooks. Palp with five segments, first three as wide as endite, last two one-half the width of third segment.

First maxilla.-Outer lobe with seven stout setae, inner lobe with three setae.

Second maxilla.-Each of the two outer lobe lappets with three or four denticulate setae at apex. Inner lobe with five setae.

Mandible.-Incisive process consisting of a double row of five small teeth; setal row with two spinelike setae. Molar process swordshaped, having a single apical seta. Palp and lacina lacking. Left and right mandibles similar.

Gnathopod.-Those of male and female similar. Dactylus with two claws, propodus with two large setae on inferior margin, carpus with four 2-pointed setae on ventral margin and a spinelike process at the triangulate apex of inferior margin.

Other peraeopods.-All similar and spindly. Seventh peraeopod dactylus with two long narrow claws; dactylus exceeds one-half the length of propodus; prodopus with three 2-pointed setae on inferior border, carpus with two 2-pointed setae on inferior border.

Uropods.-Two-branched, similar to those of the other species in the genus.

Pleopods.-Male first pleopods medially fused, posterior margin less pointed than is usual in the genus. Operculum of female pyriform, apex pointed, lateral borders setiferous. 
Types.-Holotype (U.S.N.M. No. 87412), allotype (U.S.N.M. No. 87413), and 1 male paratype (U.S.N.M. No. 87414) collected at type locality, 3 miles west of mouth of Russian River, Sonoma County, Calif., July 13, 1947, by R. J. Waidzunas and Paul B. Quyle; found in fine mud with the sea-star Luidia foliolata Grube and an apparently new species of marine isopod belonging to the genus Ianiropsis.

Geographical distribution.-Known only from the type locality.

Remarks. - This species appears to be most closely related to Pleurogonium albidum Beddard. It differs from that species in having its pleotelson widely ovate and the length of the first peraeon somite more than twice the length of the second peraeon somite. In $P$. albidum the pleotelson is narrow and the first peraeon somite is considerably shorter than the second peraeon somite.

Subgroup ANTIASINI ${ }^{9}$ Nordenstam, 1933

\section{Genus ANTIAS Richardson}

ANTIAS HIRSUTUS, new species

Figures 27, 28

Holotype.-Male, length $1.2 \mathrm{~mm}$, width at widest part of second peraeon somite $0.6 \mathrm{~mm}$.

Allotype.-Length $1.5 \mathrm{~mm}$., width $0.7 \mathrm{~mm}$.

Diagnosis.-Eyes on short stalks. Frontal margin bifurcating. Preocular lobes large but not curved outward. First antenna flagellum with three segments, last segment with a single sensory filament and a few setae at apex. Peraeon somites 1 to 4 with lateral borders straight or very slightly convex. Epimeral plates visible in dorsal view on somites 5 to 7 only. Mandibular palp not observed, apparently lacking. Body covered with many large setae. Uropods with short straight branches, peduncle slightly longer than branches and is widest at distal end.

Character of body.-Dorsal and lateral surfaces of body covered with many large setae. Cephalon and fourth peraeon somite with numerous black chromatophores; mediolateral areas of first to third peraeon somites with a longitudinal line of black chromatophores; remainder of animal cream colored.

Cephalon.-Wider than long, eyes small and on short stalks at posterolateral angles of cephalon. Preorbital lobe distinct, separated from eye by a deep lateral depression. Frontal margin emarginate, lateral lobes fringed with setae.

Peraeon-Anterior border of first somite slightly concave. Somites one to four with lateral borders straight or slightly convex, all borders fringed with long setae. Lateral borders of somites 6 and 7

- Considered by Nordenstam, p. 200, to be a subgroup of Hansen's Munnini. 
markedly convex, fringed with setae. Epimeral plates visible in dorsal view at posterolateral areas of somites 5 to 7 only.

Pleon.-Composed of a narrow, short anterior segment whose posterior border is convex and fringed with a few setae and a shieldlike
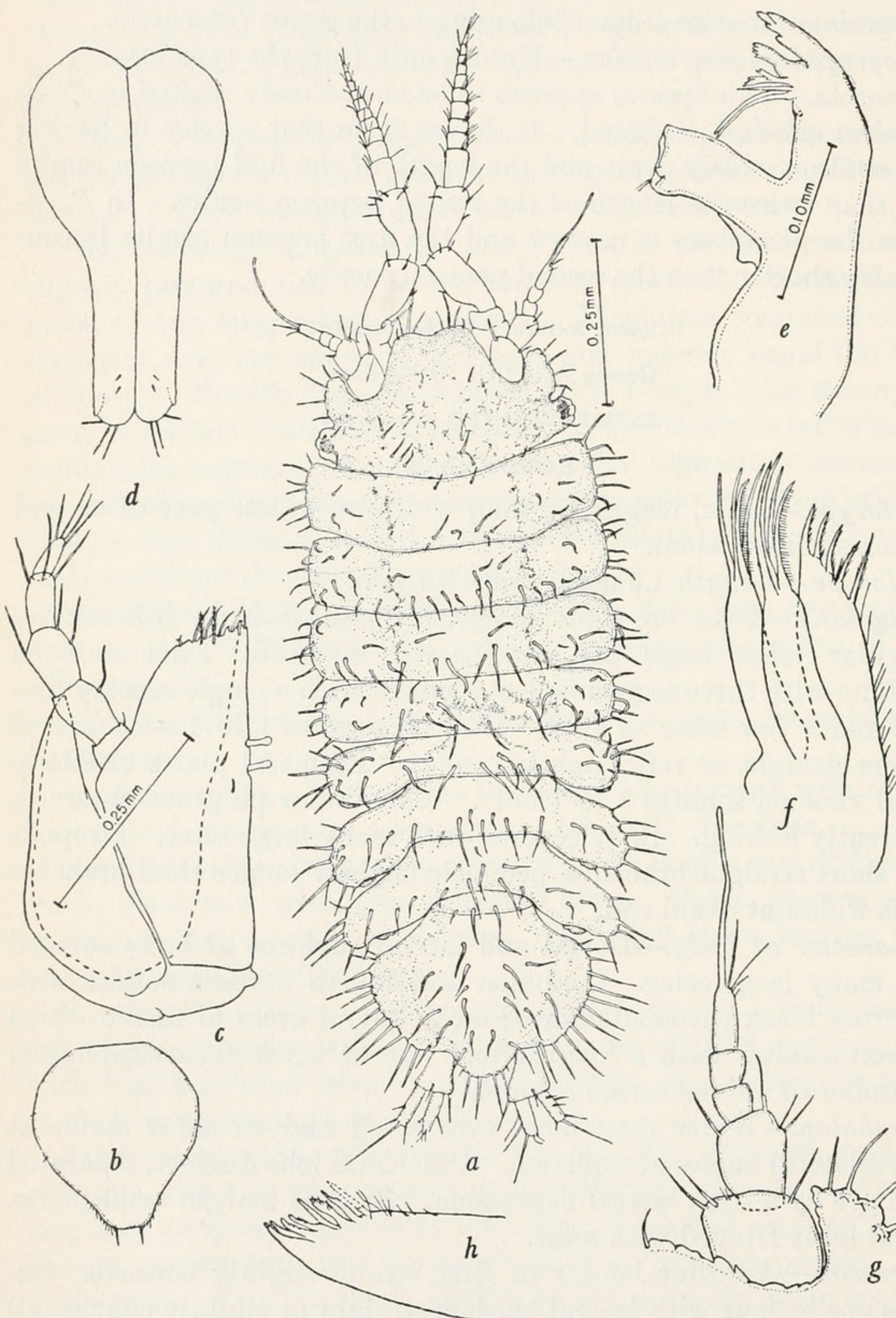

Figure 27.-Antias hirsutus, new species: $a$, Holotype male; $b$, female operculum, paratype, $c$, maxilliped, ovigerous female paratype; $d$, first pleopods, holotype; $e$, left mandible, male paratype; $f$, right second maxilla, ovigerous female paratype; $g$, first antenna, holotype; $h$, outer lobe of first maxilla, ovigerous female paratype. (Magnification as indicated by scales: $b$ same as $a$; $d$ and $g$ same as $c$; $f$ and $h$ same as $e$.) 


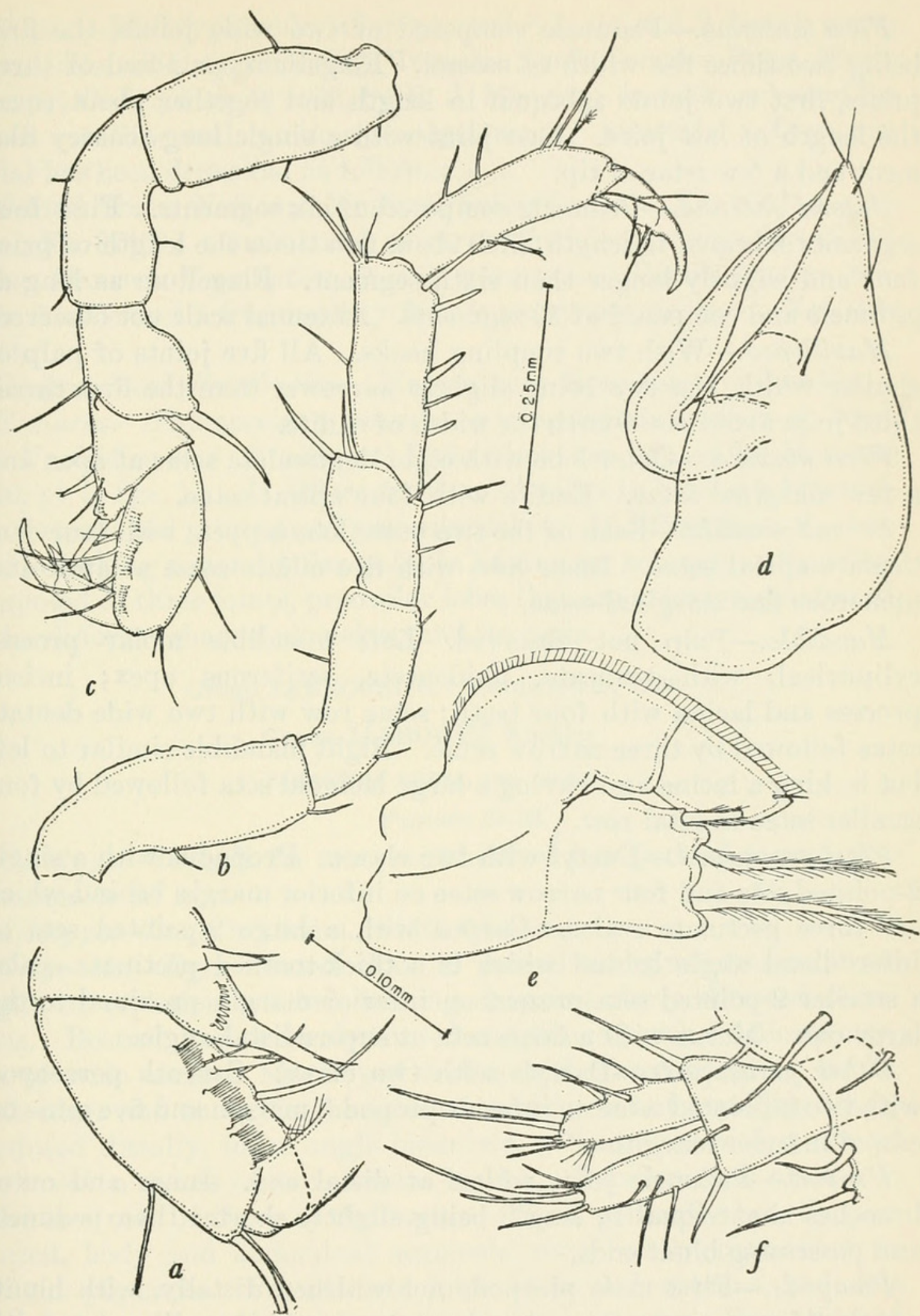

Figure 28.-Antias hirsutus, new species: $a$, Right first peraeopod, holotype; $b$, right seventh peraeopod, holotype; $c$, right first peraeopod, holotype; $d$, right second male pleopod, paratype; $e$, third male pleopod, paratype; $f$, right uropod, allotype. (Magnification as indicated by scales: $d$ and $e$ same as $a ; c$ and $f$ same as $b$.)

pleotelson, also fringed with setae and having a very distinct median lobe on posterior margin. Pleotelson posterolateral areas not projecting. 
First antenna.-Peduncle composed of two wide joints, the first being two times the width of second. Flagellum composed of three joints, first two joints subequal in length and together about equal the length of last joint. Last joint with a single long sensory filament and a few setae at tip.

Second antenna.-Peduncle composed of six segments. First four segments subequal in length, fifth about two times the length of prior four and slightly longer than sixth segment. Flagellum as long as peduncle and composed of 10 segments. Antennal scale not observed.

Maxilliped.-With two coupling hooks. All five joints of palp of similar width, last two being slightly narrower than the first three; third joint about one-fourth the width of endite.

First maxilla.-Outer lobe with eight denticulate setae at apex and a few marginal setae. Endite with four apical setae.

Second maxilla.-Each of the two outer lobe lappets with four denticulate apical setae. Inner lobe with five ciliate setae at apex and numerous fine marginal setae.

Mandible.-Palp not observed. Left mandible molar process cylindrical, with truncate, unidentate, setiferous apex; incisor process and lacina with four teeth; setae row with two wide dentate setae followed by three narrow setae. Right mandible similar to left but lacking a lacina and having a large lacinoid seta followed by four smaller setae in setal row.

First peraeopod.-Dactyl with two claws. Propodus with a single 2-pointed seta and four narrow setae on inferior margin behind which are three pectinate scales. Carpus with a large 2-pointed seta at inferodistal angle behind which is a thick-toothed pectinate scale; a smaller 2-pointed seta present on inferior margin proximal to the large one. Merus with a large seta at superodistal angle.

Other peraeopods.-Dactyls with two claws. Seventh peraeopod with two 2-pointed setae on inferior propodal margin and five setae on carpal inferior margin.

Uropod.-Peduncle joint widest at distal end. Inner and outer branches about equal in length being slightly shorter than peduncle and possessing blunt ends.

Pleopods.-First male pleopods not widened distally, with blunt, paucisetiferous tips. Second male pleopod outer lamellar plate with an acute apex; inner styliform proximal branch originating at middle of medial margin of outer branch slightly curved and extending to tip of outer branch; inner distal branch short, with blunt tip and in contact with proximal branch near its origin. Third male pleopod inner branch with three plumose setae on distal margin. Female operculum with truncate apex on either side of which is a fairly large seta. 
Types.-Holotype male, allotype, and 5 male and 2 female paratypes collected at type locality, Tomales Bluff, Tomales Point, Marin County, Calif., June 9, 1948, by R. J. Menzies; in rock and sand between coralline and laminarian algal zones; intertidal. Type material has been deposited as follows:

United States National Museum, holotype male, No. 87411; allotype, No. $87409 ; 1$ male and 1 ovigerous female paratype, No. 87410. Allan Hancock Foundation, 2 male paratypes. Pacific Marine Station, 2 male and 1 fragmentary female paratypes, accession No. 1219 Arth.

Geographical distribution.-Known only from the type locality.

Remarks.-This species appears to be intermediate between $A$. hispidus Vanhöffen and $A$. charcoti Richardson (as figured by Hodgson 1910, pl. 9, figs. 1). It differs from A. hispidus in having a bifureating rostrum and pronounced preocular lobes. It differs from $A$. charcoti in lacking a mandibular palp, in having an antennular flagellum composed of three joints, preocular lobes that are not curved outward, and a different-shaped pleotelson and uropods.

Group JAEROPSINI ${ }^{10}$ Nordenstam, 1933

\section{Genus JAEROPSIS Koehler}

JAEROPSIS DUBIA, new species

Figures 29-33

Holotype-Length $2.8 \mathrm{~mm}$., width at widest part of second peraeon somite $0.7 \mathrm{~mm}$.

Allotype.-Length $2.3 \mathrm{~mm}$., width $0.6 \mathrm{~mm}$.

Diagnosis.-Eyes located close to lateral margin. Anterolateral angles of cephalon pointed, lacking deep anteriorly directed serrations. Rostral process evenly curved and fringed with a delicate margin of wide scales. Maxilliped endite with three coupling hooks. Both inner and outer distal angles of second joint of maxilliped palp produced distally, inner angle bidentate. Pleotelson with a row of five to seven spines on each lateral border. Between each pleotelson spine is a row of three or four setae. Head generally heavily pigmented, body and abdominal segments very lightly pigmented or without pigments. Penultimate joint of second antenna peduncle with fringe of conspicuous scales on lateral margin. Exopodite of uropods with two joints.

Character of body.-Animal appears elongate and flattened. Many specimens have a wide median longitudinal thickening running the length of the peraeon. In a few specimens the thickening is not pronounced. Body smooth on dorsal surface, lacking any conspicuous setae. Color variable with the following variations observed: (1) Head black or brown, remainder of body brownish white; (2)

${ }^{10}$ Considered by Nordenstam, p. 190, to be a new group of the family Parasellidae. 
head white, body white, eyes red (albino?) ; (3) head black, a black line along midline of body from head to pleotelson (var. paucispinis, see p. 155$)$; (4) head and fourth peraeon somite black, remainder of body white (var. paucispinis, see p. 155).

Cephalon.-Wider than long. Anterolateral angles acute, projecting frontally. Frontal margin with two deep lateral concavities
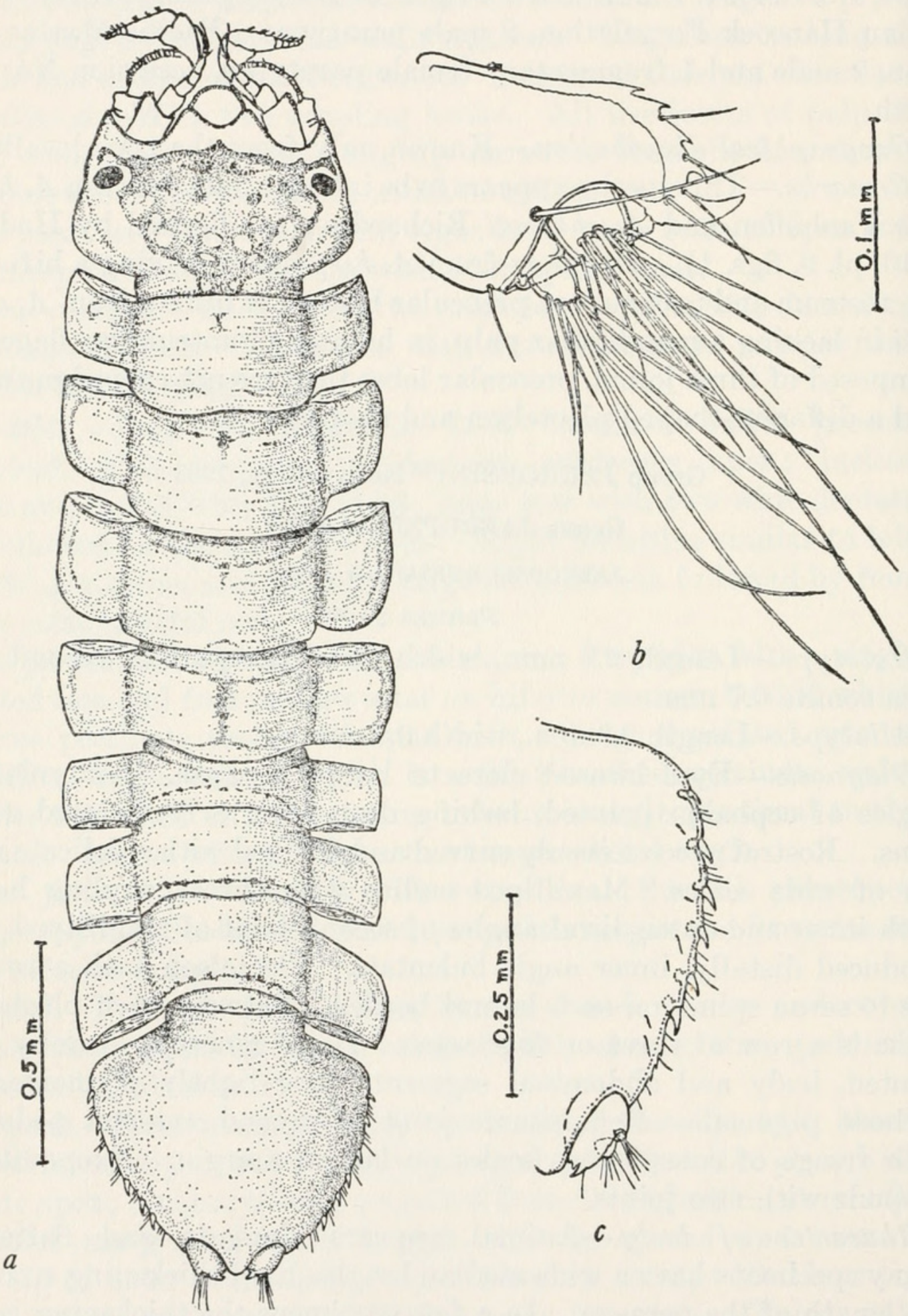

Figure 29.-Jaeropsis dubia, new species: $a$, Female paratype; $b$, inner view of uropod, paratype; $c$, pleotelson lateral border, paratype female. (Magnification as indicated by scales.) 

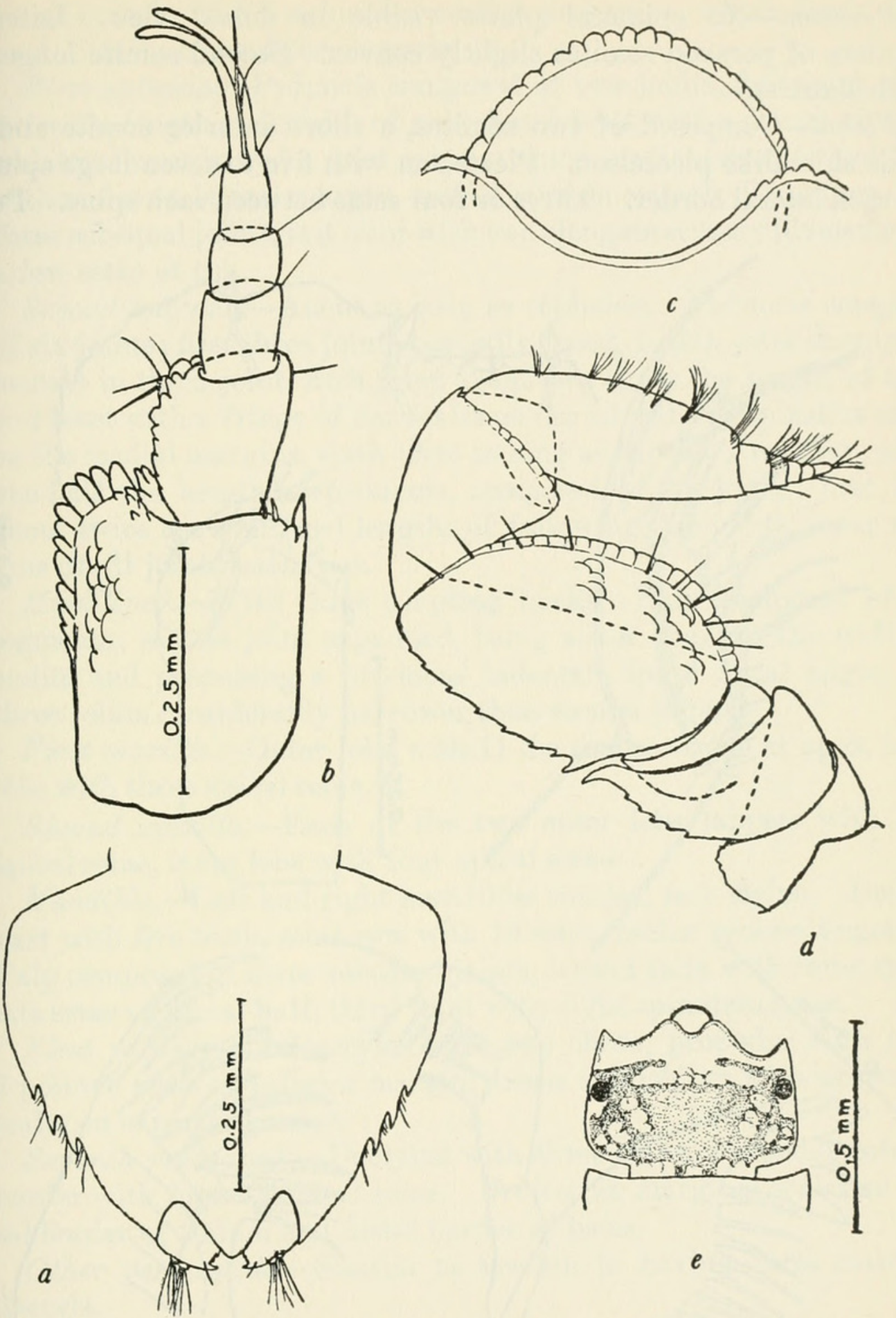

Figure 30.-Jaeropsis dubia, new species: a, pleotelson of $J$. $d$. paucispinis, new variety; $b$, first antenna, female paratype; $c$, rostral process, female paratype; $d$, second antenna, female paratype; $e$, cephalon, var. paucispinis. (Magnification as indicated by scales: $c$ same as $b ; d$ unknown.)

separated medially by a deep but more anteriorly produced concavity into which fits the rostral projection. Rostral projection semicircular in outline, bearing a conspicuous fringe of scales. Eyes dorsal, near lateral margin in upper third of cephalon. Color pattern frequently of the type shown in figure $29, a$. 
Peraeon.-No epimeral plates visible in dorsal view. Lateral borders of peraeon somites slightly convex. Second somite longest; fifth shortest.

Pleon.-Composed of two somites, a short anterior somite and a wide shieldlike pleotelson. Pleotelson with five to seven large spines on each lateral border. Three or four setae between each spine. Pos-

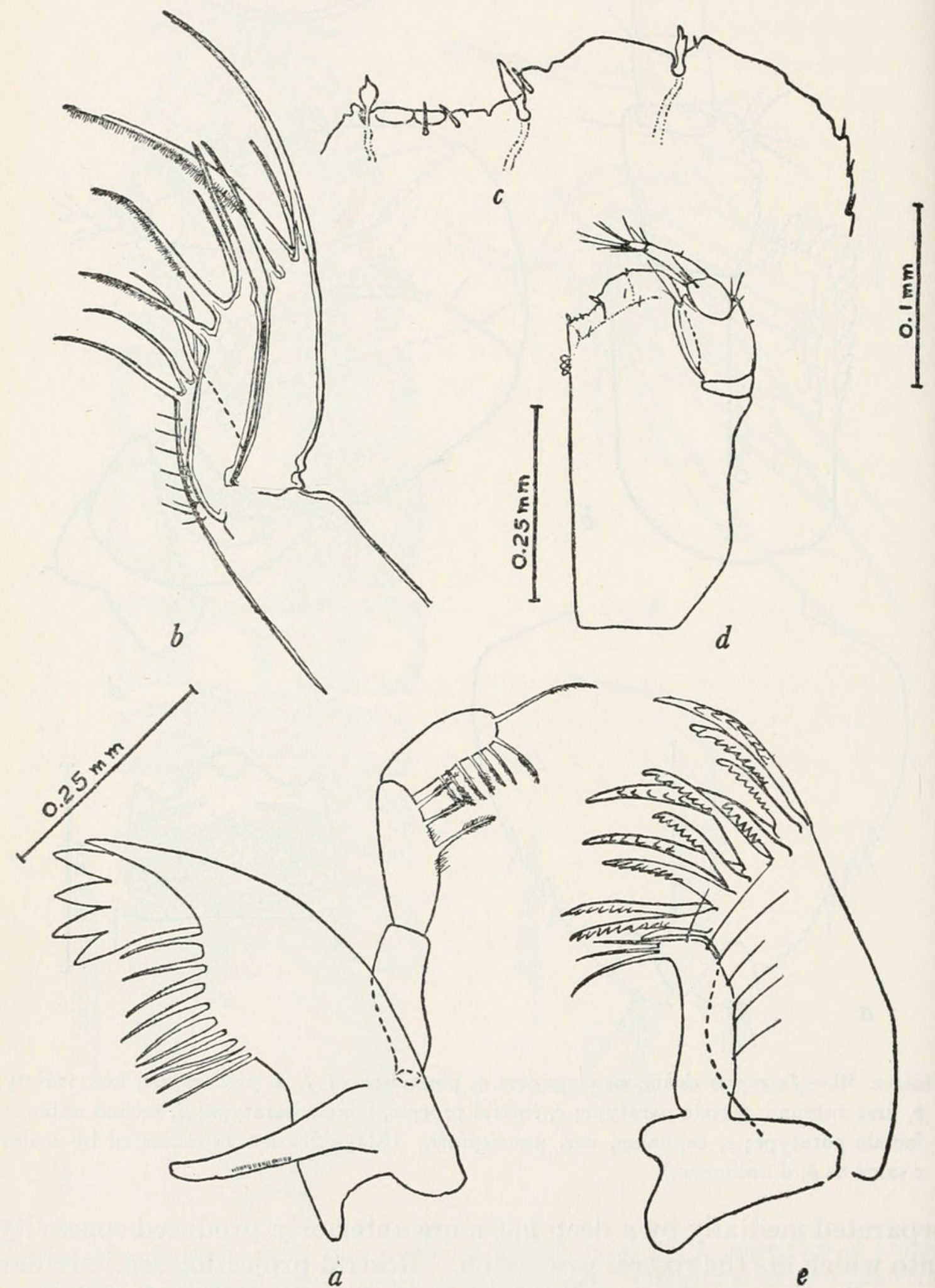

Figure 31.-Jaeropsis dubia, new species, female paratype: $a$, Left mandible; $b$, left second maxilla; $c$, distal border of maxilliped endognath; $d$, maxilliped; e, left first maxilla. (Magnification as indicated by scales: $b$ and $e$ same as $a$.) 
terior margin with a semiacute median projection, which does not extend distally beyond the uropods.

First antenna.-Peduncle composed of two joints, first joint about twice the length and width of second and beset with a fringe of scales on lateral margin and a stout spine at anteromedial edge; second joint with scales on lateral margin, medial margin smooth. Flagellum with three subequal joints, last joint with two elongate sensory filaments and a few setae at tip.

Second antenna.-About as long as cephalon. Peduncle composed of six joints ; first three joints partially fused, fourth joint deeply immersed in third joint, fifth joint about two times the length of third and beset with a fringe of flat scales on the lateral and spinelike scales on the medial margins, sixth joint as long as third. Flagellum about one-half the length of peduncle, composed of six joints; first joint about twice the combined lengths of following five joints, inner margins of all joints setiferous.

Maxilliped.-With three coupling hooks. Palp composed of five segments; second joint expanded, being about one-half the width of endite and possessing a produced bidentate inner distal angle; last three joints considerably narrower than second joint.

First maxilla.-Outer lobe with 11 denticulate setae at apex, inner lobe with three apical setae.

Second maxilla.-Each of the two outer lobe lappets with four apical setae, inner lobe with four apical setae.

Mandible.-Left and right mandibles similar, lack lacina. Incisive part with five teeth, setal row with 10 setae, molar process fingerlike. Palp composed of three subequal joints, second joint with three spinulate setae on distal half, third joint with eight spinulate setae.

First peraeopod.-Dactylus with two claws, propodus with three 2-pointed setae on inferior margin, merus and ishium with projecting scales on superior border.

Seventh peraeopod.-Dactylus with three claws, propodus inferior border with four 2-pointed setae. Projecting marginal scales on dorsal border of ishium and distal border of basis.

Other peraeopods:- Similar to seventh in having three claws on dactyls.

Uropod.-Peduncle composed of a thick joint having a large medially curved spine at distal end on medial margin; medial margin of peduncle spinulate. Endopodite cylindrical, composed of a single thick joint beset with a circle of long setae at tip. Expodite consisting of two short joints, a minute, scarcely discernible basal joint, and a nodiform distal joint whose tip bears a number of long setae.

Pleopods.-First male pleopods with produced, truncate posterolateral angles and a medially produced setiferous distal border. Female operculum pyriform, apex setiferous. 
Types.-Holotype and allotype collected at First Sled Road, north of Pacific Marine Station, Dillon Beach, Marin County, Calif., December 10, 1947, by R. J. Menzies; under stones at low-tide line ( -0.7 foot). Type material has been deposited as follows:

United States National Museum, holotype male, No. 87697 ; allotype, No. 87698; 8 male and 10 female paratypes, Nos. 87699-87700. Allan Hancock Foundation, 4 male and 14 female paratypes. Pacific Marine Station, 10 male and 14 female paratypes, accession Nos. 12291239 Arth.

Geographical distribution.-California, from Dillon Beach, Marin County, to Newport Bay, Orange County.
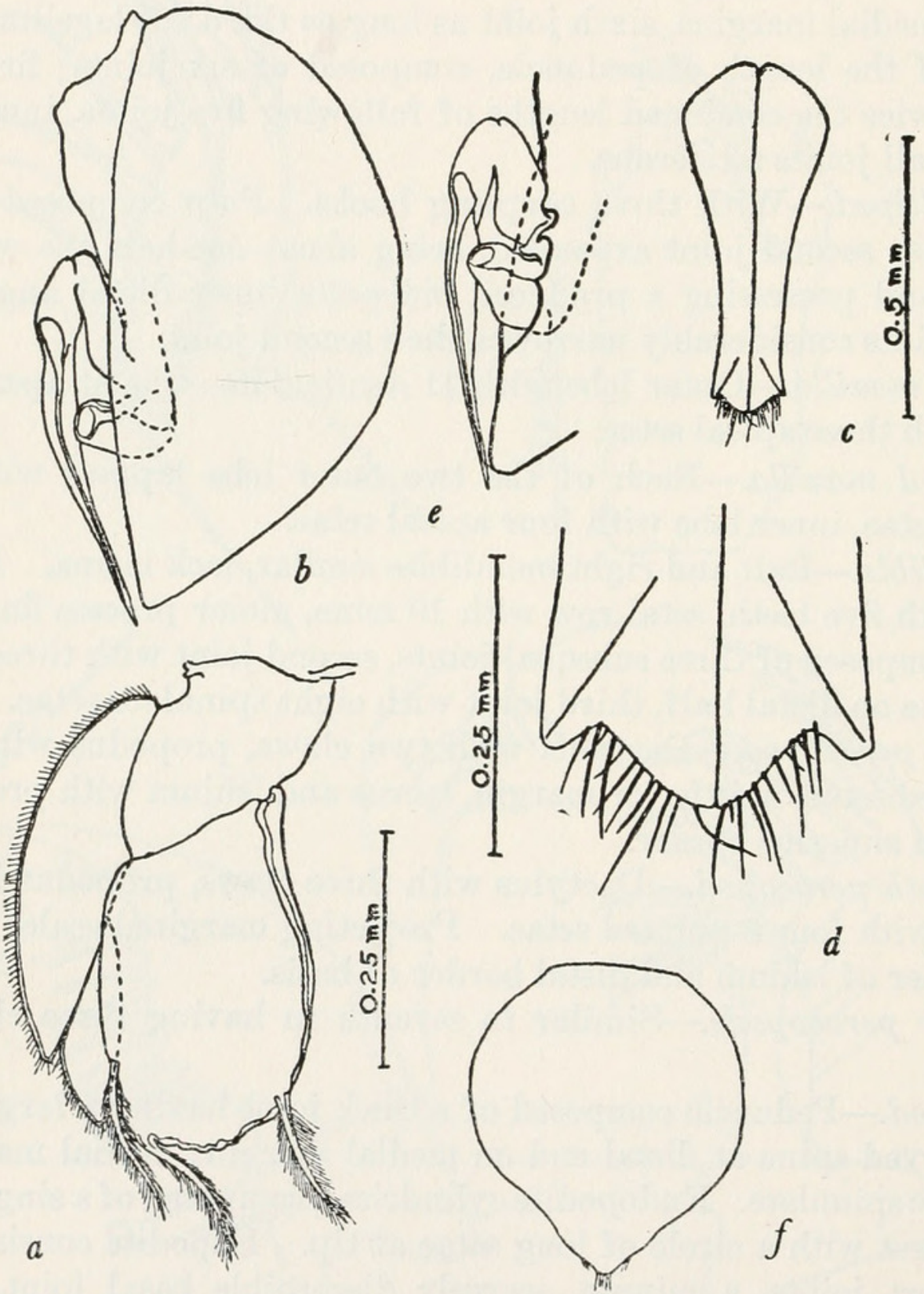

Figure 32.-Jaeropsis dubia, new species: $a$, Third male pleopod; $b$, second male pleopod; $c$, first male pleopods; $d$, distal margin of first male pleopods; $e$, inner view of medial margin of second male pleopod; $f$, female operculum. (Magnification as indicated by scales: $b$ and $e$ same as $a$ : $f$ same as $c$.) 


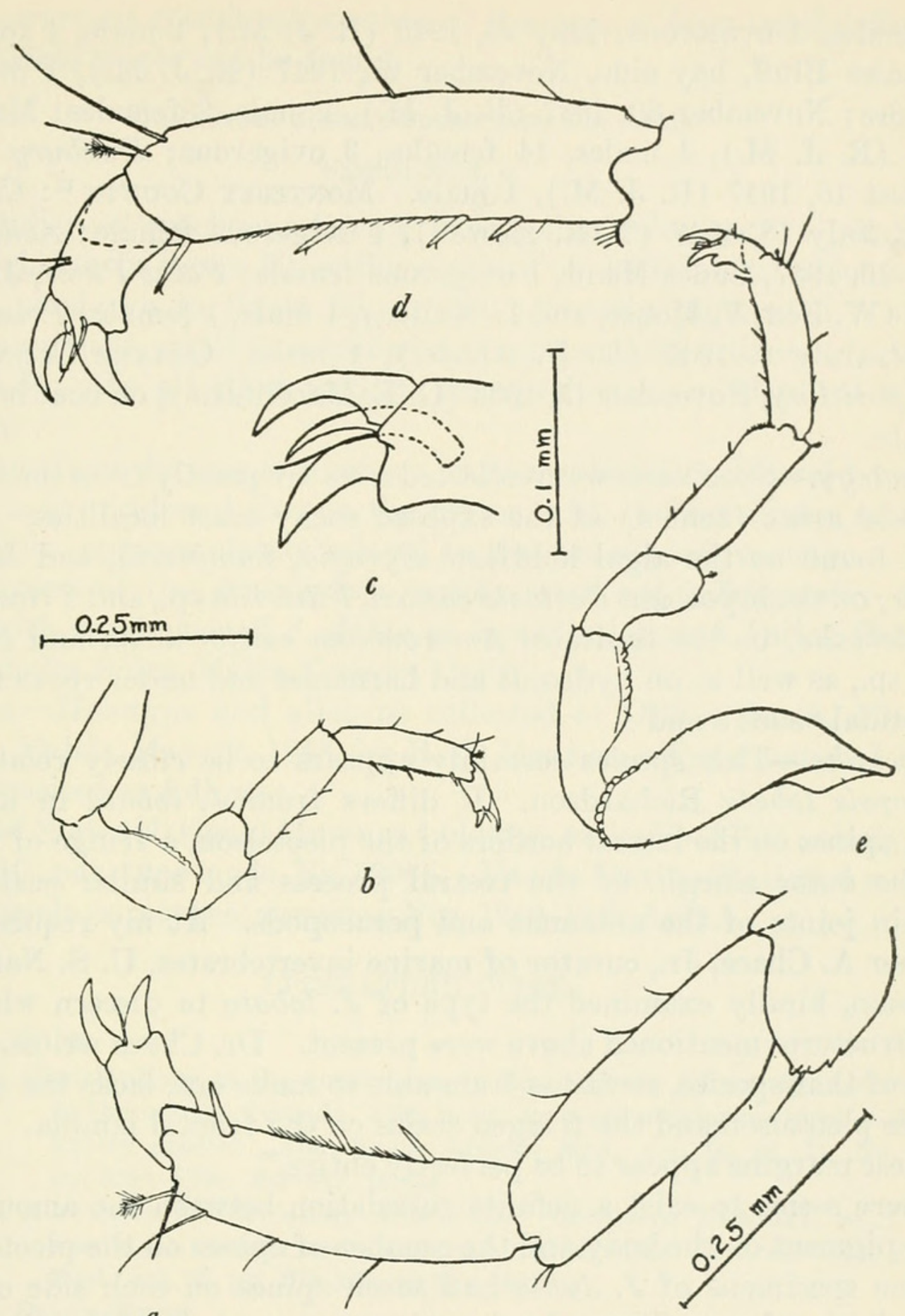

$a$

Figure 33.-Jaeropsis dubia, new species: $a$, Distal joints of right first peraeopod; $b$, right first peraeopod, female paratype; $c$, dactylus of seventh peraeopod; $d$, distal joints of seventh peraeopod, female paratype; $e$, seventh peraeopod, female paratype. (Magnification as indicated by scales: $d$ same as $a$; $e$ same as $b$.)

Material examined.-Specimens were examined that had been collected from the following California localities:

Marin County: Dillon Beach, Second Sled Road, August 14, 1947 (R. J. M.), 2 males; December 10, 1947 (R. J. M.), holotype and allotype; February 21, 1948 (R. J. M.), 2 males, 2 females; March 22, 1948 (R. J. M.), 1 male, 4 females; March 28, 1948 (R. J. M.), 1 male (albino); May 12, 1948 (R. J. M.), 6 males, 9 females, 2 ovigerous; Tomales Point, Tomales Bluff, ocean side, August 18, 1947 (R. J. M.), 
2 females, 1 ovigerous; May 23, 1948 (R. J. M.), 1 male, 1 female; Tomales Bluff, bay side, November 28, 1947 (R. J. M.), 1 male, 2 females; November 30, 1947 (R. J. M.), 1 male, 2 females; May 23, 1948 (R. J. M.), 4 males, 14 females, 3 ovigerous; Duxbury Reef, August 15, 1947 (R. J. M.), 1 male. Monterey Countr ${ }^{11}$ : Carmel Cove, July 18, 1947 (T. R. Howell), 1 ovigerous female; Asilomar, July 16, 1947, Cadet Hand, 1 ovigerous female; Point Pinos, July 3, 1947 (W. Fox, V. House, and L. Kellen), 1 male, 1 female; Pescadero Point, July 8, 1947 (D. P. Abbott), 1 male. Orange Countr ${ }^{12}$ : Newport Bay, November 15, 1933 (G. E. MacGinitie), on boat bottom, 1 male.

Ecology.-Specimens were collected most frequently from the lowest exposed areas (zone 4) of the exposed rocky coast localities. They were found on the algal holdfasts Egregia, Laminaria, and Macrocystis; on the bryozoans Costazia costazi, Filicrisia sp., and Tricellaria occidentalis; on the tunicates Amaroucium californicum and Synoicum sp., as well as on hydroids and barnacles and under rocks in the intertidal zones 3 and 4 .

Remarks.-This species certainly appears to be closely related to Jaeropsis lobata Richardson. It differs from $J$. lobata in having stout spines on the lateral borders of the pleotelson, a fringe of scales on the outer margin of the rostral process and similar scales on certain joints of the antennae and peraeopods. At my request Dr. Fenner A. Chace, Jr., curator of marine invertebrates, U. S. National Museum, kindly examined the type of J. lobata to discern whether the structures mentioned above were present. Dr. Chace writes, "The type of that species, so far as I am able to make out, lacks the spines on the pleotelson and the fringed scales on the frontal lamina. Both of these margins appear to be perfectly entire."

There seems to exist a definite correlation between the amount of dark pigment on the body and the number of spines on the pleotelson. Albino specimens of $J$. dubia had seven spines on each side of the pleotelson; other specimens having pigments concentrated on the head but few pigments elsewhere had five to six spines on either side of the pleotelson. The var. paucispinis, described below, in which more pigments are present, has from two to three spines on either side of the pleotelson. Richardson's J. lobata, a species having more pigment than any I have examined, lacks spines on the pleotelson lateral borders. Although the correlation between the number of pleotelson spines and the amount of body pigment might indicate that $J$. dubia is not distinct from $J$. lobata, other differences as enumerated above

\footnotetext{
${ }^{11}$ Specimens lent to writer by Dr. Frank A. Pitelka, Zoology Department, Un1versity of California. Paratypes donated to U. S. National Museum.

${ }^{12}$ Specimen lent to writer by Dr. Fenner A. Chace, Jr., curator of marine invertebrates, U. S. National Museum.
} 
seem to warrant specific separation of the two, at least until definite intermediate stages can be found.

JAEROPSIS DUBIA PAUCISPINIS, new variety

Figure $30, a, e$

A number of specimens having a cephalon color pattern similar to that shown in figure $30, e$, three spines on each lateral pleotelson border, as shown in figure 30, a, and a heavily pigmented fourth peraeon segment, might be considered as representing a distinct variety of $J$. dubia. In all other respects the specimens are identical with J. dubia.

One specimen having two spines on each pleotelson lateral border and a black middorsal line on the perion with the remainder of the body white, appears closely related to the paucispinis variety.

Specimens of the paucispinis variety were not infrequently collected with specimens of $J$. dubia at localities around Dillon Beach and Tomales Point, Marin County, Calif.

Types.-Holotype and allotype collected at Dillon Beach, Marin County, Calif., May 12, 1948, by R. J. Menzies. Type material has been deposited as follows:

United States National Museum, holotype male, No. 87711; allotype, No. 87710 ; paratype made, No. 89055. Pacific Marine Station, 4 males and 1 female paratypes, accession Nos. 1240-1242 Arth.

\section{LITERATURE CITED}

BARNARD, K. H.

1914. Contributions to the crustacean fauna of South Africa, 3; Additions to the marine Isopoda, with notes on some previously incompletely known species. Ann. South African Mus., vol. 10, pt. 11, No. 16, pp. 325a-358a, 359-442, 12 pls.

1925. A revision of the family Anthuridae (Crustacea Isopoda), with remarks on certain morphological peculiarities. Journ. Linn. Soc. Zool., vol. 35, pp. 109-160, 10 figs., 4 pls.

BedDard, Frank Evers.

1886. Report on the Isopoda collected by H. M. S. Challenger during the years 1873-76, pt. 2. Challenger Reports, Zoology, vol. 17, 175 pp., 25 pls.

Boone, Pearl Lie.

1918. Description of ten new isopods. Proc. U. S. Nat. Mus., vol. 54, pp. 591-604, 4 pls.

1923. New marine tanaid and isopod Crustacea from California. Proc. Biol. Soc. Washington, vol. 36, pp. 147-156.

Bovallidos, Carl.

1881. Ianthe, a new genus of Isopoda. Kongl. Svenska Vet.-Akad. Handl., vol. 6 , No. 4, pp. $3-14,3$ pls. [Not seen.] 
FEE, A. R.

1926. The Isopoda of Departure Bay and vicinity, with descriptions of new species, variations and color notes. Contr. Can. Biol. and Fish., new ser., vol. 3 , No. 2 , pp. 15-47, 1 pl.

GurJanova, Eupraxia.

1933. Contributions to the isopod fauna of the Pacific Ocean, No. 2; New species of Gnathiidae and Asellota. Explorations des Mers. U. R. S. S. Leningrad, No. 19 , pp. 78-97.

\section{Hangen, Hans Jacob.}

1916. Crustacea Malacostraca III, The Order Isopoda. Danish Ingolf-Exped., vol. 3 , No. 5, 262 pp., 16 pls.

HARgEr, Oscar.

1880. Report on the marine Isopoda of New England and adjacent waters. Rep. U. S. Comm. Fish and Fisheries for 1878, pt. 6, pp. 297-462, 13 pls.

\section{Hatch, Melville H.}

1947. The Chelifera and Isopoda of Washington and adjacent regions. Univ. Washington Publ. Biol., vol. 10, pp. 155-274.

Hodgson, T. V.

1910. Crustacea, IX: Isopoda. National Antarctic Expedition 1901-1904, vol. 4, No. 3, Zoology and Botany, 77 pp., 10 pls.

Nordenstam, AKe.

1933. Marine Isopoda of the families Serolidae, Idotheidae, Pseudidotheidae, Arcturidae, Parasellidae and Stenetriidae mainly from the South Atlantic. Further Zool. Res. Swedish Antarctic Exped. 19011903, vol. 3, No. 1, 284 pp., 78 figs., 2 pls.

RICHARDSon, Harriet (Mrs. Harriet Richardson Searle).

1899a. Key to the isopods of the Pacific coast of North America, with descriptions of twenty-two new species. Proc. U. S. Nat. Mus., vol. 21, pp. 815-869, 34 figs.

1899b. [Reprint of 1899a.] Ann. Mag. Nat. Hist., ser. 7, vol. 4, pp. 157-187, 260-277, 321-338.

1900. Synopses of North American invertebrates, VIII : The Isopoda. Amer. Nat., vol. 34, pp. 207-230, 295-309.

1904a. Isopod crustaceans of the Northwest coast of North America. Harriman Alaska Expedition, Crustacea, vol. 10, pp. 213-230.

1904b. [Reprint of 1904a.] Proc. U. S. Nat. Mus., vol. 27, pp. 657-681, 39 figs.

1905a. Isopods of the Alaskan Salmon Investigation. Bull. U. S. Bur. Fish., vol. 24, pp. 209-221.

1905b. A monograph on the isopods of North America. U. S. Nat. Mus. Bull. 54, liii +727 pp., 740 figs.

StafFord, Blanche E.

1913. Studies in Laguna Beach Isopoda. II B. Journ. Ent. and Zool., vol. 5, pp. 182-188, figs. $6-10$. 


\section{$2 \mathrm{BHL}$ Biodiversity Heritage Library}

1951. "New marine isopods, chiefly from northern California, with notes on related forms." Proceedings of the United States National Museum 101(3273), 105-156. https://doi.org/10.5479/si.00963801.101-3273.105.

View This Item Online: https://www.biodiversitylibrary.org/item/31795

DOI: https://doi.org/10.5479/si.00963801.101-3273.105

Permalink: https://www.biodiversitylibrary.org/partpdf/30773

\section{Holding Institution}

Smithsonian Libraries

\section{Sponsored by}

Smithsonian

\section{Copyright \& Reuse}

Copyright Status: NOT_IN_COPYRIGHT

Rights: https://www.biodiversitylibrary.org/permissions/

This document was created from content at the Biodiversity Heritage Library, the world's largest open access digital library for biodiversity literature and archives. Visit BHL at https://www.biodiversitylibrary.org. 